\title{
PETROGENESIS OF MARTIAN SULFIDES IN THE CHASSIGNY METEORITE
}

JEAN-PIERRE LORAND ${ }^{1}$, SYLVAIN PONT $^{2}$, VINCENT CHEVRIER $^{3}$, AMBRE LUGUET $^{4}$, BRIGITTE ZANDA, ${ }^{2,}$ ROGER HEWINS ${ }^{2}$

1 Laboratoire de Planétologie et Géodynamique à Nantes, CNRS UMR 6112,

Université de Nantes, 2 Rue de la Houssinère, BP 92208, 44322 Nantes Cédex 3,

France.jean-pierre.lorand@univ-nantes.fr.

2 Institut de Minéralogie, de Physique des Matériaux, et de Cosmochimie (IMPMC) - Sorbonne Université- Muséum National d'Histoire Naturelle, UPMC Université Paris 06, UMR CNRS 7590, IRD UMR 206, 61 rue Buffon, 75005 Paris, France.

3 W.M. Keck Laboratory for Space and Planetary Simulation, Arkansas Center for Space and Planetary Science, MUSE 202, University of Arkansas, Fayetteville, AR 72701, USA.

4 Rheinische Friedrich-Wilhelms-Universität Bonn, Steinmann Institut für Geologie, Mineralogie und Paläontologie, Poppelsdorfer Schloss, 53115 Bonn, Germany.

Corresponding author: jean-pierre.lorand@univ-nantes.fr 
ABSTRACT

The Chassigny meteorite, a Martian dunite, contains trace amounts (0.005 vol.\%) of Fe-Ni sulfides, which were studied from two polished mounts in reflected light microscopy, Scanning Electron Microscope (SEM) and Electron Microprobe (EMP). The sulfide phases are, by

decreasing order of abundance, nickeliferous $(0-3 \mathrm{wt} \% \mathrm{Ni})$ pyrrhotite with an average composition $\mathrm{M} 0.88 \pm 0.01 \mathrm{~S}(\mathrm{M}=\mathrm{Fe}+\mathrm{Ni}+\mathrm{Co}+\mathrm{Cu}+\mathrm{Mn})$, nickeliferous pyrite $(0-2.5 \mathrm{wt} \% \mathrm{Ni})$, pentlandite, millerite and unidentified $\mathrm{Cu}$ sulfides. Pyrrhotite is enclosed inside silicate melt inclusions in olivine and disseminated as polyhedral or near spherical blebs in intergranular spaces between cumulus and postcumulus silicates and oxides. This sulfide is considered to be a solidification product of magmatic sulfide melt. The pyrrhotite $\mathrm{Ni} / \mathrm{Fe}$ ratios lie within the range expected for equilibration with the coexisting olivine at igneous temperatures. Pyrite occurs only as intergranular grains, heterogeneously distributed between the different pieces of the Chassigny meteorite. Pyrite is interpreted as a by-product of the low- $\mathrm{T}\left(200^{\circ} \mathrm{C}\right)$ hydrothermal alteration events on Mars that deposited $\mathrm{Ca}$ sulfates + carbonates well after complete cooling. The shock that ejected the meteorite from Mars generated post-shock temperatures high $\left(300^{\circ} \mathrm{C}\right)$ enough to anneal and rehomogenize Ni inside pyrrhotite while pyrite blebs were fractured and disrupted into subgrains by shock metamorphism. The negligible amount of intergranular sulfides and the lack of solitary sulfide inclusions in cumulus phases (olivine, chromite) indicate that, like other Martian basalts so far studied for sulfur, the parental melt of Chassigny achieved sulfide-saturation at a late stage of its crystallization history. Once segregated, the pyrrhotite experienced a late-magmatic oxidation event that reequilibrated its metal-to-sulfur ratios.

\section{INTRODUCTION}

Mars is an S-rich planet (King and McLennan 2010 and references therein). Oxidized sulfur is a major component of the Martian regolith (up to $8 \mathrm{wt} \% \mathrm{SO}_{2}$; Foley et al. 2003). Martian sulfates originated from magmatic degassing of $\mathrm{SO}_{2}$ (Tian et al. 2015; Kerber et al. 2015), although 
a minor contribution from acid weathering of pre-existing Fe sulfides is not unlikely (Dehouck et al. 2012). Owing to their much higher FeO contents, Martian basalts are able to transfer twice as much $\mathrm{S}$ as dissolved FeS from the mantle to the Martian crust compared to terrestrial basalts (Ding et al. 2015 and references therein).

Mars is the only telluric planet of the solar system that can also be studied from meteorites. More than a hundred igneous rocks ejected from the Martian crust are now available in our collections and are referred to as $\mathrm{SNC}$ meteorites, in addition to a few meteorites containing pieces of the lithology of the early Martian crust (McSween and Treiman, 1998; Treiman et al., 2000). SNC meteorites comprise hypovolcanic porphyritic basalts (Shergottites), clinopyroxene cumulates (Nakhlites) and dunite cumulates (Chassignites) from extrusive flows (McSween 2001; McSween and McLennan, 2014 and references therein). Studies of shergottites provided invaluable information on sulfur and sulfides in the interior of Mars. Accessory pyrrhotite was reported as the predominant Fe-sulfide, coexisting with pentlandite and chalcopyrite (Lorand et al. 2005; Gattacceca et al. 2013; Franz et al. 2014; Baumgartner et al. 2017a). It is well known that pyrrhotite phases are oxygen fugacity sensors because trivalent $\mathrm{Fe}^{3+}$ can balances the charge deficiency due the missing $\mathrm{Fe}^{2+}$ in the pyrrhotite structure (Pratt et al. 1994; Mycroft et al. 1995; Mikhlin and Tomashevic 2005; Skinner et al. 2004). The range of metal-to-sulfur atomic ratios $(0.99<\mathrm{M} / \mathrm{S}<0.9$ where $\mathrm{M}=$ divalent metals $\mathrm{Fe}, \mathrm{Ni}, \mathrm{Co}, \mathrm{Cu}, \mathrm{Mn})$ published for shergottite pyrrhotites is consistent with the range of $\mathrm{fO}_{2}$ conditions inferred for the Martian mantle (FMQ + 0.5 to FMQ-3; Herd et al. 2002; Papike et al. 2009; FMQ = Fayalite-Magnetite-Quartz buffer). FeNi sulfides also are of prime importance for the budget of highly siderophile elements (Platinumgroup elements-PGEs, Au, Re) of Martian magmas, which behave as strongly chalcophile elements in metal-free magmatic rocks like SNC meteorites (Baumgartner et al. 2017a).

The cumulate nakhlites differ from shergottites by their paucity of Fe-Ni sulfides, which are mainly composed of strongly metal-deficient pyrrhotite phases $(\mathrm{M} / \mathrm{S}=0.875 \pm 0.01$; Chevrier et al. 2011; see also Day et al. 2006). These pyrrhotite compositions are not in equilibrium with the 
redox conditions inferred for the mantle source of parental melts (Chevrier et al., 2011). Moreover, hydrothermal alteration products (e.g., pyrite) have been identified in nahklites (Bunch and Reid, 1975; Greenwood et al. 2000a). The origin of pyrrhotite non-stoichiometry (magmatic degassing, assimilation of $\mathrm{S}$ or post-igneous hydrothermal modification) is still debated (Day et al. 2006; Chevrier et al. 2011; Franz et al. 2014). Chassignites may provide separate constraints because they share many characteristics with nakhlites, including their inferred mode of occurrence as extrusive flow(s) on Mars, their crystallization at ca. $1.3 \mathrm{Ga}$ and their ejection ages at ca. $11 \mathrm{Ma}$ indicating a single ejection event for chassignites and nakhlites (Harvey and McSween 1992; Treiman et al. 2000; Nyquist et al. 2001; McSween 2001). Chassignites consist of only three meteorites, Chassigny (Floran et al. 1978; Johnson et al. 1991), northwest Africa (NWA) 2737, a strongly shocked hot desert find from northwest Africa (Beck et al. 2006) and NWA 8694, a ferroan chassignite recently discovered from northwest Africa (Hewins et al. 2015). However, chassignites remain the least well known of the SNC regarding Fe-Ni sulfides, except the highly shocked sample NWA 2737 that was deeply modified by impact metamorphism (Lorand et al. 2012).

Our paper is focused on the Chassigny meteorite that fell on October 3, 1815 in HauteMarne, eastern France (Pistollet 1816). It is the oldest fall of a Martian meteorite ever observed on Earth and, as such, the historical starting point of SNC studies. Shock metamorphism effects in this meteorite are much weaker than in NWA 2737 (Langenhorst and Greshake, 1999). Unlike northwest Africa meteorites, it escaped hot desert alteration and the related damage to igneous and hydrothermal sulfide assemblages (Lorand et al 2005; 2015). Chassigny may allow us to address the behavior of Fe-Ni sulfides during cooling and hydrothermal circulation in the cumulate parts of lava flows as well as the timing of $\mathrm{S}$ saturation in ferropicritic Martian magmas.

\section{PETROGRAPHY OF CHASSIGNY}

The Chassigny meteorite is a dunitic cumulate composed of cumulus olivine (91.6 vol. \%) 
and chromite (1.4 vol. \%), intercumulus pyroxenes (5 vol.\%) and feldspar (1.7 vol. \%), and accessory phases (potassium feldspar, apatite, baddeleyite, zirconolite, silica, ilmenite, rutile and Fe sulfides (Floran et al. 1978; Meyer 2012). The rock microtexture is adcumulate, except where intercumulus minerals are concentrated (Fig. 1). Olivine is Fe-rich ( $\left.\mathrm{Fo}_{68}\right)$. The pyroxenes are Carich, poikilitic augite $\left(\mathrm{Wo}_{33} \mathrm{En}_{49} \mathrm{Fs}_{17}\right)$ containing lamellae of exsolved Ca-poor pyroxene $\left(\mathrm{Wo}_{3} \mathrm{En}_{68} \mathrm{Fs}_{17}\right)$ (Johnson et al. 1991) and poikilitic pigeonite (Wadhwa and Crozaz 1995). Interstitial feldspar is Na-rich $\left(\mathrm{An}_{32} \mathrm{Ab}_{64} \mathrm{Or}_{4}\right)$. Chassignites are interpreted as cumulates from ultramafic (ferropicritic) magma(s) emplaced as a komatiitic flow or sill and crystallized at high oxygen fugacity compared to shergottites (FMQ $\pm 1 \log$ unit vs FMQ +0.5 to FMQ $-3 \log$ unit; Herd et al. 2002; Papike et al. 2009; Delaney and Dyar 2001; Treiman et al. 2007; McCubbin et al. 2013; Baumgartner et al. 2017b). During cooling and solidification, chromite was likely the first phase to crystallize because it is found as inclusions in olivine, followed by olivine.

Olivine encloses large (up to $350 \mu \mathrm{m}$ across) spherical to elliptical melt inclusions (Floran et al. 1978; Varela et al. 2000; McCubbin and Nekvasil 2008; Nekvasil et al. 2007; McCubbin et al. 2013). These melt inclusions are interpreted as entrapment of cogenetic melt during magmatic growth of olivine (McSween and Treiman 1998). Most of these inclusions are partially crystallized and contain euhedral minerals interpreted as daughter minerals: low-Ca pyroxene (orthopyroxene) and high-Ca augitic pyroxene together with $\mathrm{Cl}$-apatite and/or Al-rich chromite, magnetite, kaersutitic amphibole and Ti-biotite (Johnson et al. 1991; Morikawa et al. 2006; McCubbin et al. 2013). These daughter minerals are embedded in a K-Si-Al-rich alkali feldspar glass (alkali maskelenyite of McCubbin et al., 2013) showing significant $\mathrm{Cl}(2500-1500 \mathrm{ppm})$ and $\mathrm{H}_{2} \mathrm{O}(0.74$ wt\%) contents (Boctor et al., 2006; McCubbin and Nekvasil 2008).

Secondary minerals of Martian origin (trace amounts of Ca-carbonate, Ca-sulfate and Mgcarbonate) were identified in some cracks inside Chassigny (Wentworth and Goodings 1994). Sulfates display non mass-dependent $\Delta^{33} \mathrm{~S}$ isotopic compositions deviating from 0 that support a pre-terrestrial origin for these minerals (Farquhar et al. 2000; Franz et al. 2014). 
The samples in this study consisted of two polished mounts of Chassigny $\left(\sim 3 \mathrm{~cm}^{2}\right)$, which were provided by the Muséum National d'Histoire Naturelle (MNHN), Paris, France. Sulfides were first characterized with an Olympus $\mathrm{BH} 2$ optical microscope operating in reflected light. They were studied in conventional (high-vacuum) mode with a Tescan VEGA II LSU Scanning Electron Microscope (SEM) equipped with a silicon drift (Bruker) Energy Dispersive Spectrometer (EDS) (Muséum National d'Histoire Naturelle-MNHN, Paris, France). Sulfides were localized in the two samples thanks to mosaics composed of stitched BSE maps with a view field of $905 \mu \mathrm{m}$ each and an overlap of $5 \%$ (Fig. 1). These maps allowed sulfide modal abundances to be estimated using their high BSE contrast with non-sulfide minerals (PhotoshopTM toolbar). The minimum size of sulfide particle that can be resolved this way was around $10 \mu \mathrm{m}$. Then, each sulfide detection was checked by optical microscopy and EDS spectra collected during manual scan over the two polished mounts. This procedure helped to take into account the smallest sulfide grains $(<5 \times 5$ $\mu \mathrm{m})$ not detected on the BSE maps and avoided overestimation of sulfide abundances from minerals with similar brightness (baddeleyite, ilmenite, chromite).

Major element compositions of sulfides were first determined with the SEM-EDS at the MNHN using $15 \mathrm{keV}$ accelerating voltage with a PhiRoZ EDS standardless procedure and a working distance of $15.4 \mathrm{~mm}$ corresponding to the geometrical configuration of the chamber of the Tescan VEGA II LSU SEM for semi quantitative analyses. Each grain texture was carefully studied in BSE mode at high magnification to avoid analytical contribution of silicate microinclusions or alteration products. The spatial resolution of the SEM (a few hundred nanometers) allowed tiny contaminants to be resolved and discrete sulfide inclusions inside olivine-hosted melt inclusions to be analyzed semi quantitatively. Contaminants, however small, were monitored by analyzing silica and phosphorus which are major elements in the minerals 
usually surrounding sulfides. Only the analyses giving undetectable amount of $\mathrm{Si}$ and $\mathrm{P}(<0.1 \mathrm{wt} \%)$ were considered to be reliable. Moreover, the accuracy and precision of SEM analyzes were checked by replicate analyses of a terrestrial troilite (Del Norte County; California) previously analyzed with both EMP and SEM (Table 1).

Ninety percent of the sulfides analyzed with EDS were reanalyzed with EMP using wavelenght dispersive spectrometer (WDS; Table 2 and supplementary data). The analyses were done with the Camparis (Centre d'analyse microsonde de Paris) SX 100 and SXFive Cameca electron microprobes, at $15 \mathrm{KeV}$ accelerating voltage, a beam diameter of $2-3 \mu \mathrm{m}$ and a $20 \mathrm{nA}$ as beam current sample. Elemental concentrations were determined using the following standards: natural pyrite for $\mathrm{S}$ and $\mathrm{Fe}$, sphalerite for $\mathrm{Zn}$ and pure metals for $\mathrm{Fe}, \mathrm{Ni}, \mathrm{Co}, \mathrm{Cu}$, As. Silica and oxygen were added to the analytical routine to check any possible contribution of the sulfide analyses by surrounding silicates. Hematite $\left(\mathrm{Fe}_{2} \mathrm{O}_{3}\right)$ and wollastonite $\left(\mathrm{CaSiO}_{3}\right)$ were used as external calibration standard for these two elements. The accuracy of EMP analyses was checked by repeated analysis of the Del Norte County natural troilite. This external standard was analyzed every $10-15$ analyses to evaluate potential variation on metal-to-sulfur ratios (M/S). Comparisons with the published electron microprobe analyses of this troilite indicate that the accuracy and precision of the EMP determination of the pyrrhotite $(\mathrm{M} / \mathrm{S})$ ratio is currently better than $\pm 1 \%$ (Lorand et al. 2012; Chevrier et al. 2011; Gatacceca et al. 2013; Table 1).

Olivine in our pieces of Chassigny was analyzed by WDS on the Camparis Cameca SXFive electron microprobe at the Université Paris VI, using $15 \mathrm{keV}$ and $10 \mathrm{nA}$, a beam diameter of 2-3 $\mu \mathrm{m}$ and natural (wollastonite, rutile, albite, forsterite, rhodonite, $\mathrm{K}$ feldspar, hematite) and synthetic minerals $\left(\mathrm{Mn}_{2} \mathrm{O}_{3}, \mathrm{Cr}_{2} \mathrm{O}_{3}, \mathrm{NiO}\right)$ as standards (Table 3 and supplementary data). Count times were 10 s/peak, $10 \mathrm{~s} /$ backgrounds. Detection limits were $0.05 \mathrm{wt} \%$ for major elements. The mean composition of olivine is shown in Table 3.

\section{RESULTS}


Five sulfide phases were identified in our polished mounts of Chassigny. These are by decreasing order of abundance: pyrrhotite, pyrite, pentlandite, $\mathrm{Cu}$-sulfides and millerite. Sulfides occur as both enclosed and intergranular sulfides.

\section{Enclosed sulfides}

The sulfides do not occur as solitary sulfide blebs in cumulus minerals (olivine and chromite). Enclosed sulfides occur exclusively inside melt inclusions in olivine (Fig. 2a). Olivinehosted enclosed sulfides are a pyrrhotite phase of very small size ( $1 \times 1$ to $5 \times 3 \mu \mathrm{m})$. Pyrrhotite may occur as prismatic crystals with hexagonal cross sections that may occasionally be ragged on one face (Fig. 2a). The pyrrhotite is commonly associated with chromite, apatite, orthopyroxene, clinopyroxene and kaersutite, which represent crystallization products from the melt fraction trapped inside the melt inclusions (McCubbin and Nekvasil 2008). The sulfide grain usually occurs close to the inner walls of the cavity; it may also be occasionally located within polycrystalline aggregates of pyroxenes, chromite and apatite.

\section{Intergranular sulfides}

Intergranular sulfides range in size from less than $100 \mu \mathrm{m}^{2}$ to $600 \mu \mathrm{m}^{2}$ for the largest ones $(30 \mu \mathrm{m} \times 20 \mu \mathrm{m})$ (Fig. 3). Their surface area represents less than 0.005 vol. \% of the total surface investigated in this study. Intergranular sulfides are randomly scattered throughout our two polished mounts of Chassigny (Fig. 1). They fill space at boundaries between olivine grains as well as triple junctions between olivine and pyroxenes, or olivine and chromite. Some intergranular sulfides are partly embedded inside intergranular feldsparic melt pockets (Fig. 2b). The shape of intergranular sulfides depends on their location in the meteorite. Sulfide grains embedded in feldsparic melt pockets may preserve rounded morphologies (Fig. 2c). Intergranular sulfide may show straight contacts against olivine crystals (Fig. 2d). Those grains located at triple junctions between cumulus minerals (olivine, chromite) or intercumulus pyroxenes are ellipsoidal to polyhedral bodies with convex-inward grain boundaries and low dihedral angles (Fig. 2e). 
a strong optical anisotropy in reflected light while the pyrite is isotropic, enabling easy distinction with marcasite. Pyrrhotite and pyrite are randomly distributed throughout the two polished mounts investigated. Pyrrhotite is predominant in one polished mount while pyrite is for the second one. Pyrrhotite and pyrite have been found to coexist in a handful of single grains. In that case, a pyrite rim is observed around the pyrrhotite and the interface between the two phases is corrugated.

Pyrrhotite grains are either optically homogeneous or cut by contorted fracture planes (Fig. 2c-e). However, pyrrhotite is slightly fractured compared with major silicates, chromite, and pyrite (see below). Pentlandite was identified with its optical properties in reflected light (Fig. 2d) and EDS spectra in five pyrrhotite blebs over the several tens studied in detail with the SEM. In those grains pentlandite is concentrated as tiny discrete bodies toward the margins of their host pyrrhotite (granule exsolution, Fig. 2d,e). Copper was detected in two EDS spectra of pyrrhotite/pentlandite and pyrite suggesting that $\mathrm{Cu}$-sulfides too small to be accurately identified may also be present in Chassigny intergranular sulfides. One pyrite bleb encloses a Ni-rich sulfide (millerite-NiS) which was identified with the SEM (Table 2).

Euhedral pyrite crystals have not been observed. Intergranular pyrite grains show the same size and morphologies as pyrrhotite grains: rounded to ellipsoidal bodies or polyhedral grains with low dihedral angles when forming triple junctions with surrounding olivine (Fig. 2f-h). On average, pyrite appears to be more fractured compared to pyrrhotite. Fracture networks are evenly distributed, ranging from a few parallel cracks to regularly spaced cell-like systems; in most extreme cases, pyrite crystals were fragmented into particles of less than 1-2 micrometres across (Fig. 2f-h). Fracture planes are generally confined to the pyrite alone (i.e., they do not cut across surrounding silicates). Pyrite shows incipient alteration by Fe-oxyhydroxides that selectively replace pyrite along its fracture planes (Fig. 2h).

\section{PHASE CHEMISTRY}

Only a few olivine-hosted pyrrhotite microinclusions were large enough for EMP analysis. 
Their metal-to-sulfur atomic ratio ranges from 0.86 to 0.90 (Fig. 4; Table 2). These compositions correspond to hexagonal $\left((\mathrm{Fe}, \mathrm{Ni})_{9} \mathrm{~S}_{10}\right)$ and monoclinic $\left(\left(\mathrm{Fe}, \mathrm{Ni}_{7}\right)_{7} \mathrm{~S}_{8}\right)$ crystal structures in the lowtemperature phase diagram of natural pyrrhotites (Kissin and Scott, 1982). Nickel concentrations vary between 1.3 and $2.8 \mathrm{wt} \%$ (Fig. 5).

Intergranular pyrrhotite exhibits very similar compositions to those of enclosed pyrrhotite (Fig. 4). EDS and WDS analyses provided reproducible results, as long as the grains analyzed were more than $10 \mu \mathrm{m}$ across and devoid of any pentlandite exsolutions (Table 2 and Table S1). The $\mathrm{M} / \mathrm{S}$ of intergranular pyrrhotites spread over a restricted range (0.87 - 0.92), with an average centered on $0.88 \pm 0.01$ (one standard deviation). The lowest ratio corresponds to intergranular pyrrhotite showing incipent crystallization of pyrite. The highest ratios $(>0.9)$ were found in the pyrrhotite grains showing pentlandite micro-exsolution (e.g., Po1a16; Table 2) and/or Cu-rich areas (e.g., Po7c10; Table 2). These metal-rich pyrrhotite compositions were probably contaminated by pentlandite exsolutions. Nickel concentrations range between 1 and $3 \mathrm{wt} \% \mathrm{Ni}$, irrespective of the $\mathrm{M} / \mathrm{S}$ ratios and the occurrence of pentlandite (Fig. 5). The highest Ni contents ( $>2 \mathrm{wt} \%$ ) were found in interstitial pyrrhotite grains located between cumulus olivine crystals. Cobalt contents are below limits of detection $(<0.2 \mathrm{wt} \%)$ as are $\mathrm{Cr}$ contents except in the vicinity of chromite. Pyrrhotite is also poor in oxygen $(<1 \mathrm{wt} \%$; Fig. 6$)$.

The few EDS analyses of pentlandite correspond to Fe-rich compositions (Table 2), as expected for this sulfide when it is associated with pyrrhotite (Misra and Fleet, 1973).

Pyrite is slightly metal enriched compared to stoichiometric $\mathrm{FeS}_{2}(\mathrm{Fe} / \mathrm{S}$ atomic ratio $=0.50$ 0.54; Fig. 6). EDS and EMP analyses show heterogeneous distribution of $\mathrm{Ni}$, without any welldefined Ni-rich spots as reported in NWA 7533 euhedral pyrite grains (Lorand et al. 2015). On average, pyrite is depleted in Ni compared to pyrrhotite $(<0.1-1 \mathrm{wt} \%$; Fig. 5). Its Co content is below limits of detection for most analyses (Table 2). Among other minor and trace elements, pyrite contains copper (up to $0.23 \mathrm{wt} \%$ ) and some oxygen. High oxygen contents (3.4 wt\%) correlate with high $\mathrm{M} / \mathrm{S}$ ratios thus indicating decreasing $\mathrm{S}$ content at increasing oxygen content 


\section{DISCUSSION}

The sulfide phases documented here were previously reported by Floran et al. (1978) and Greenwood et al (2000b). The olivine-hosted sulfides and intergranular sulfides define two sulfide assemblages I) pyrrhotite ( \pm pentlandite $\pm \mathrm{Cu}$ sulfides), II) pyrite ( \pm millerite $\pm \mathrm{Cu}$-sulfides). Assemblage I is typical of SNC igneous meteorites either as intergranular assemblages (Lorand et al. 2005; Chevrier et al. 2011; Franz et al. 2014) or as olivine-hosted sulfides reported in lherzolitic and picritic (olivine-rich) shergottites (Gattaccecca et al. 2013; Baumgartner et al. 2017a). The igneous origin of assemblage I in the Chassigny meteorite is supported by its occurrence in olivinehosted melt inclusions and the shape of intergranular pyrrhotite grains ranging from nearly spherical droplets to polyhedral grains with concave-inward margins. By its compositions and its shape, assemblage I can be interpreted as a solidification product of magmatic sulfide melts (e.g. Naldrett et al. 1967; Craig and Kullerud 1969; Raghavan 2004; Naldrett 2005 and references therein). By contrast, pyrite is a post-igneous replacement product of the original magmatic sulfide assemblage on Mars because it occurs only as an intergranular, heterogeneously distributed mineral in the intercumulus spaces, while showing similar crystalline shape as pyrrhotite. Before further discussion of their origin, it is necessary to assess the effect of shock metamorphism and postshock alteration that affected both sulfide assemblages.

\section{Shock effect and terrestrial alteration.}

Both pyrrhotite and pyrite are fractured, especially the pyrite. Fracture affects all minerals in the Chassigny meteorite, silicates, phosphates, oxides and sulfides. Olivine-hosted melt inclusions are surrounded by radial fracture planes which may reach intergranular pores of the rock. These fracture networks are usually ascribed to the shock event that launched the meteorite into space, ca 11 Myr ago (Langenhorst and Greyshake 1999, Malavergne et al. 2002; Meyer 2012 
and references therein). However, pyrite displays a much higher density of fracture, resulting locally in finely granulated pyrite blebs (Fig. 2h). Pyrite behaves as an extremely brittle mineral resulting in cataclastic deformation during deformation and metamorphism (McClay and Ellis 1983). One may note that at temperatures up to $400^{\circ} \mathrm{C}$ and confining pressures up to $1000 \mathrm{MPa}$, pyrite strain rates range from $10^{-4}$ to $10^{-7} \mathrm{sec}^{-1}$ (McClay and Ellis 1983 and ref. therein). Generally, the brittle deformation results in randomly fractured fragments (cataclastic texture), as documented in Chassigny pyrite (Fig. 2g,h). Pyrrhotite behaves more plastically and recrystallizes easily (Cox 1987). Langenhorst and Greshake (1999) studied in detail the shock metamorphism features of the Chassigny meteorite by optical and transmission electron microscopy (TEM). These authors documented i)-the activation of numerous planar fractures and dislocations in olivines coexisting with discontinuous fractures, strong mosaicism and clino-/orthoenstatite inversion, ii)-fracturing, reduced birefringence (conversion to diaplectic glass (maskelynite), and planar deformation features in the plagioaclase. Taken altogether, these shock features indicate a shock pressure of about $35 \mathrm{Gpa}$ with a post-shock temperature of about $300^{\circ} \mathrm{C}$ (Malavergne et al. 2002) without the impact melting found in other Martian meteorites. The post shock temperature of $300^{\circ} \mathrm{C}$ proposed for Chassigny was too low to remelt pyrite which is a stable phase below $743^{\circ} \mathrm{C}$ under P-T conditions of planetary surfaces (Toulmin and Barton, 1964). However it was high enough to anneal and rehomogenize any pentlandite exsolution inside the pyrrhotite: at this temperature, the Chassigny pyrrhotite compositions plot in the single-phase domain corresponding to monosulfide solid solution (Mss), the high-temperature precursor of pyrrhotite and pentlandite in the Fe-Ni-S ternary diagram of Fig. 7. It may be deduced from Fig. 7 that the few pentlandite blebs observed in Chassigny pyrrhotite exsolved during post-shock cooling by heterogeneous nucleation (Etschman et al. 2004).

The persistence of pyrite and metal-deficient pyrrhotite in the Chassigny meteorite is consistent with a much lower post-shock temperature and weaker shock effect compared to NWA 2737. Bogard and Garrison (2008) suggested that NWA 2737 experienced a post-shock 
temperature to $300-500 \mathrm{C}$, perhaps $800 \mathrm{C}$. i.e. closer to the upper thermal stability of pyrite. Indeed, Lorand et al. (2012) reported for this meteorite, minute amounts (0.01 vol.\%) of a pyritefree, metal-saturated Fe-Ni sulfide assemblage consisting of a Ni-poor troilite (FeS, sometimes $\mathrm{Cr}$ bearing) coexisting with micrometer-sized native Ni-Fe alloys, in addition to a few Os-Ir alloys. Lorand et al. (2012) proposed that the high shock pressure (55 Gpa) coupled with strong heating triggered sulfur degassing that reduced pyrite and metal-deficient pyrrhotite into FeS and native metal alloys. This shock-induced S loss is supported by the highly resorbed and denticulated shape of sulfide blebs and their spongy textures (Lorand et al., 2012). An FeS phase was reported to occur locally in the Chassigny meteorite by Floran et al. (1978). Chevrier et al. (2011) interpreted this phase as an analytical artifact in the EMP analyses of pyrrhotite. However, as shown by the sulfide assemblage of NWA 2737, it may have been produced by local S loss during shock metamorphism. Gattaceca et al. (2013) reported similar evolution of pyrrhotite compositions toward FeS in the highly shocked olivine-phyric shergottite Tissint. If present, this stoichiometric FeS phase is likely a very minor phase in the Chassigny meteorite. We did not identify it in our two polished mounts (Fig. 4). Franz et al. (2014) did not detect the Acid Volatile Sulfides (AVS) fraction that would correspond to this FeS phase in their chemical extraction of sulfur from Chassigny.

Pyrite has been oxidized after crystallization as shown by its elevated (though variable) oxygen contents detected by EMP analyses and local replacement by Fe oxyhydroxides. The latter alteration of pyrite by Fe oxyhydroxides is a typical feature of weathering that releases $\mathrm{S}$ as soluble sulfate while leaving insoluble trivalent Fe as Fe oxyhydroxides (Wattmuff 1974; Thornber 1975; Lorand et al. 2005; Zurfluh et al. 2013; Hayes et al. 2014). In humid and aerated conditions, pyrite can be oxidized by oxygen or trivalent Fe following the reactions below (Jerz and Rimstidt 2004; Liu et al. 2009; Huminicky et al. 2009) :

$\mathrm{FeS}_{2}+3.5 \mathrm{O}_{2}+\mathrm{H}_{2} \mathrm{O}=\mathrm{Fe}^{3+}+2 \mathrm{H}^{+}+2 \mathrm{SO}_{4}{ }^{2-}$

$\mathrm{FeS}_{2}+14 \mathrm{Fe}^{3+}+8 \mathrm{H}_{2} \mathrm{O}=15 \mathrm{Fe}^{2+}+16 \mathrm{H}^{+}+2 \mathrm{SO}_{4}{ }^{2-}$ 
This alteration event is likely a terrestrial feature because Fe oxyhydroxides were observed to occur only within the finely granulated pyrite blebs showing cataclastic microtextures (Fig. 2h). However, the Chassigny meteorite is an observed fall and not a hot desert find: its pieces were collected immediately after their arrival on the Earth surface (Pistollet, 1816), which certainly prevented them from extensive weathering by atmospheric agents (Meyer, 2012). However, oxidation may have occurred during the curation of the meteorite for the last 200 years in the MNHN collection. It is well known from museum curators and mining operation that pyrite can alter over days or months if kept in a humid and oxygenated environment (Huminicky et al. 2009). There is independent evidence of terrestrial contamination and/or alteration involving water, sulfur and sulfides in the Chassigny meteorite. Wentworth and Gooding (1994) reported traces of massive, fine-grained Ca-sulphate in some vugs in Chassigny's fusion crust which could indicate either terrestrial contamination or post-fall leaching of hygroscopic, pre-terrestrial salts from the interior. Terrestrial hydrogen exchange was documented by Leshin et al. (1996) via D/H ratios. Brandon et al. (2000) documented disturbance in the bulk-rock ${ }^{187} \mathrm{Re} /{ }^{188} \mathrm{Os}$ ratio of Chassigny possibly due to late terrestrial remobilization of Re liberated from altered pyrite.

The sensitivity of Chassigny pyrite to oxidation can be ascribed to the extensive fracturing that generated highly granulated domains inside pyrite grains. In impact regolith breccia NWA 7533, terrestrial weathering was guided by shock-induced microfracturing of pyrite (Lorand et al. 2015). The size of the pyrite grains plays a key part in the oxidation process which destroys museum samples of pyrite and marcasite (Rimstidt and Vaughan 2003). It is well known that milling and grain size reduction increases the rate and susceptibility of Fe-bearing phases to oxidation processes (Williamson and Rimstidt 1994; Pratt et al. 1994; Nesbitt et al. 1998; Thomas et al. 1998, 2001). Conchoidal fractures that produce surface sites of reduced coordination with dangling bonds are more reactive compared to normal crystallographic surfaces sites (Chandra and Gerson 2011; Todd et al. 2003). Compared with pyrite, Chassigny pyrrhotite shows almost unaltered, oxygen-poor compositions which are at odds with theoretical expectations. Pyrrhotite is 
expected to be far more reactive to oxidation than pyrite (Janzen et al. 2000; Mikhlin and Tomashevic 2005). The weathering of pyrrhotite under the influence of atmospheric oxygen proceeds approximately 20-100 times faster than that of pyrite (Belzile et al. 2004). This faster oxidation rate is usually ascribed to the lower crystal symmetry of pyrrhotite that results from the vacancy of Fe atoms in the crystal structure (Janzen et al. 2000, Harries et al. 2013). Concerning Chassigny pyrrhotite, its very low degree of alteration could be due to extensive recrystallization at $300^{\circ} \mathrm{C}$ during the shock metamorphism event that probably healed fracture planes, thus reducing preferential pathways for oxidation.

\section{Martian hydrothermal alteration and the origin of pyrite.}

By its location in interstitial pores, pyrite clearly postdates solidification of the cumulate phases of the Chassigny meteorite. Crystallization of pyrite at the igneous stage is very unlikely as it is not stable above $743^{\circ} \mathrm{C}$ (Toulmin and Barton 1964). Moreover, its precipitation at this temperature would require unrealistically high sulfur fugacity (close to the domain of liquid native S) compared with that indicated by pyrrhotite composition (Fig. 8). Both lines of evidence make pyrite a subsolidus phase. Pyrite can exsolve from pyrrhotite by cooling but exsolution should produce Py inside Po, as wormlike textures (e.g., Lorand and Alard 2011) or discrete granules as usually observed in magmatic sulfide assemblages (Craig and Vokes 1993; Hall 1986; Hollwell et al. 2017 and references therein). Precursor high-temperature monosulfide solid solution (Mss) can produce only $30 \%$ pyrite by weight this way (Naldrett et al. 1967). Assuming that pyrite exsolved from metal-deficient pyrrhotite with a general composition of $\mathrm{M}_{0.88} \mathrm{~S}$, the exsolution process should have followed path B in Fig. 8 on cooling; hence the pyrrhotite should display increasing metal-tosulfur ratio down to 0.92 at $\mathrm{T}<200^{\circ} \mathrm{C}$, significantly off the compositional range measured for the Chassigny meteorite (Fig. 4). If exsolved from the pyrrhotite, then pyrite should be homogeneously distributed within our two polished mounts of Chassigny, and observed both as inclusions and intergranular sulfides. 
The shape of pyrite grains that display the same morphologies as coexisting igneous pyrrhotite grains argues instead for local replacement of the pyrrhotite by pyrite. The same replacement reaction was postulated for pyrite from other Martian meteorites (e.g. ALH 84001;

Shearer et al. 1996; the nahklites Nakhla, Governador Valadares and Lafayette; Bunch and Reid

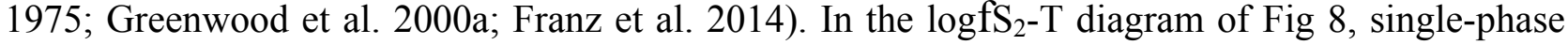
pyrite grains observed in Chassigny reflect local excursion of the fugacity of sulfur within the $\operatorname{logfS_{2}}{ }_{2} \mathrm{~T}$ area of pyrite stability, i.e. well above the FMQ-Po reference curve taken as a marker of redox conditions for Chassigny. This cooling path may track input of external S raising the apparent fugacity of sulfur (Hall 1986). There is published evidence for post-igneous external input of S in the Chassigny meteorite. Wentworth and Gooding (1994) reported discontinuous veins of Ca-sulphate (gypsum $\left(\mathrm{CaSO}_{4} \cdot 2 \mathrm{H}_{2} \mathrm{O}\right)$ or bassanite $\left.\left(\mathrm{CaSO}_{4} \cdot 1 / 2 \mathrm{H}_{2} \mathrm{O}\right)\right)$, Ca-carbonate, and $\mathrm{Mg}$ carbonate along fractures in primary igneous minerals. These sulfate and carbonate salts also contain traces of $\mathrm{Cl}$ and $\mathrm{P}$, which supports their precipitation from short-lived, cold, saline, aqueous solutions well after the igneous crystallization of the Chassigny cumulate (Bridges et al., 2001). Sulfur isotopic compositions measured on the Chassigny meteorite add further constrains on the origin of pyrite. Greenwood et al (2000b) provided seven in-situ ion microprobe analyses of this sulfide; all show negative Canyon Diablo Troilite (CDT)-normalized $\delta^{34} \mathrm{~S}\left(-4.6 \%{ }_{0}<\delta^{34} \mathrm{~S}<-1.5 \%\right.$, off the baselines for mantle-derived Martian sulfur $\left(\delta^{34} S=0\right)$ as defined from shergottite meteorites (Franz et al. 2014). Greenwood et al (2000b) inferred low-temperature $\left(200^{\circ} \mathrm{C}\right)$ exchange of volatile components $(\mathrm{S}, \mathrm{C}, \mathrm{H})$ between olivine cumulate flows and regolith by hydrothermal fluids. Likewise, Franz et al. (2014) documented mass-independent fractionation (MIF) in Chassigny Ca sulphates $\left(\Delta^{33} \mathrm{~S}=0.0336 \pm 0.008 \%\right.$ ) which also indicates recycling of surface sulfur.

Chassigny pyrite may have formed from direct sulfurization of preexisting igneous pyrrhotite by S-bearing hydrothermal fluids because the latter imparted their $\mathrm{S}$ isotopic composition to the pyrite, different from that of initial igneous sulfides. Different pathways can be assumed for this transformation, depending on the initial assemblage of the igneous sulfide and 
chemical exchanges between sulfides and hydrothermal fluid. For example, the NiS-rich mineral identified as millerite with the SEM in one pyrite grain could derive from a pyrrhotite-pentlandite precursor, if this reaction also operated with Fe loss to the fluid (Fig. 9). Pyrite and millerite are stable together below $230^{\circ} \mathrm{C}$ (Craig 1973; Misra and Fleet 1973), in agreement with the temperature range inferred for hydrothermal contamination of the Chassigny meteorite (Greenwood et al., 2000b). A volume loss of several tens percent of original sulfides is expected for this reaction (e.g. Holwell et al. 2017, and ref. therein) but hard to quantify as the Chassigny sulfides experienced shock effects that heavily fractured the pyrite and modified its porosity.

There are other possible pathways for pyrite formation in the Chassigny meteorite. Pyrrhotite can be oxidized into pyrite via reactions such as:

$$
2 \mathrm{FeS}+1 / 2 \mathrm{O}_{2}=\mathrm{FeS}_{2}+\mathrm{FeO}
$$

or

$$
3 \mathrm{FeS}+\mathrm{H}_{2} \mathrm{O}+3 \mathrm{O}_{2}=\mathrm{FeS}_{2}+\mathrm{H}^{+}+\mathrm{HSO}_{4}^{-}+2 \mathrm{FeO}
$$

in humid and aerated conditions (Watmuff 1974; Pratt et al. 1994; Harries et al. 2013; Kanipayacharoen and Boudreau 2013). However, such reactions are considered to be much less likely because the Chassigny cumulate flow was exposed to subsurface conditions of dry Amazonian Mars (Nyquist et al., 2001), a period of little water and dissolved oxygen available for oxidative dissolution of pyrrhotite.

Our study, coupled with literature data, reveal strong heterogeneity in the distribution of pyrite both within and between each piece of the same meteorite. The pyrite/pyrrhotite modal ratio is estimated to vary from ca 1 to 2 between our two polished mounts. Greenwood et al (2000b) identified only pyrite in a sulfide-poor chip of Chassigny. This heterogeneity is an expected outcome of the numerous parameters that drive pyrite-producing reactions. For instance, pyrrhotite armored inside olivine-hosted sulfide inclusions escaped to alteration while unarmored portions within intercumulus material have been heterogeneously replaced. One may also argue that pyrite did not systematically nucleate because its formation is very sluggish below $200^{\circ} \mathrm{C}$ (Craig, 1973; 
Rickard and Luther 2007 and references therein). Additional evidence of internal heterogeneity is the heterogeneous distribution of marcasite. Floran et al. (1978) identified this sulfide, based only on its optical properties, while we did not find it in our polished mounts of Chassigny. Marcasite was reported to form at $\mathrm{T}<150^{\circ} \mathrm{C}$ and $\mathrm{pH}<4$ by Fleet (1978) and Craig and Vokes (1993 and references therein). One may argue that the post-shock annealing event at $300^{\circ} \mathrm{C}$ converted marcasite to pyrite. On Earth, for example, marcasite in sulfide ore deposits is converted to pyrite by natural annealing at relatively low $\left(<200^{\circ} \mathrm{C}\right)$ temperatures (Fleet 1978; Hall 1986; Murowchick, 1992). The heterogeneous distribution of marcasite may thus fingerprint some heterogeneities in the Chassigny meteorite related to shock metamorphism, as do the occasional occurrences of FeS (troilite).

\section{Petrogenesis of the igneous sulfide assemblage I.}

\section{Sulfur ultradepletion in Chassigny indicates sulfur-undersaturated parental melt.}

The lack of single-phase pyrrhotite inclusions indicates that the parental melt for the Chassigny meteorite presumably did not segregate immiscible sulfide liquids over the interval of olivine and chromite crystallization. Sulfur dissolves in reduced Martian basalts as $\mathrm{FeO}+1 / 2 \mathrm{~S}_{2}=$ $\mathrm{FeS}+1 / 2 \mathrm{O}_{2}$ (Ding et al., 2015 and references therein). The $\mathrm{S}$ content necessary to saturate the hypothetical parental melt of Chassigny is available from experiments relevant to Martian lavas (Ding et al. 2015), coupled with the FeOT content (19.95 - 20.33 wt\%; Johnson et al. 1991; Filiberto 2008; He et al. 2013). Giesting et al. (2015) estimated that partial melting started at $\mathrm{P}>2$ Gpa $(170 \mathrm{~km}$ ) so this putative melt was able to dissolve at best $4000 \pm 1000 \mathrm{ppm} \mathrm{S}$ (Ding et al. 2015). Its actual $\mathrm{S}$ content can be estimated around $3600 \mathrm{ppm}$ by coupling the most conservative estimate of the S content of the Martian mantle (360 \pm 120 ppm S; Wang and Becker 2017) with the degree of partial melting estimated for Chassignites (10\%; Wadhwa and Crozaz 1995). Of course, melting degrees in excess of $10 \%$ would have decreased the $\mathrm{S}$ content of the melt proportionally, thus making it S-undersaturated once leaving its mantle source. Our conclusion is 
supported by platinum-group element (PGEs) analyses. Baumgartner et al (2017b) reported detectable concentrations of $\mathrm{Ru}$ (up to $\sim 160 \mathrm{ppb} \mathrm{Ru}$ ) in chromite of Chassigny and NWA 2737. This element (and other PGEs as well) should have been preferentially incorporated into sulfide melts if any sulfide had been present during chromite precipitation (Brenan et al., 2016 and references therein). Baumgartner et al (2017b) concluded that the parental melt of Chassigny started crystallizing chromite under sulfide-undersaturated conditions, as documented for other Martian magmas sampled by shergottites (e.g. Brandon et al. 2012; Baumgartner et al. 2017a).

The late-magmatic achievement of $\mathrm{S}$ saturation is also consistent with the very low amount of Fe-Ni sulfides in the Chassigny meteorite. Previous studies reported bulk-rock S contents of similar order of magnitude in Chassigny (mean $260 \pm 130 \mathrm{ppm} \mathrm{S}$; McSween, 2014) and nakhlites, corresponding to ca., $0.06 \pm 0.03 \mathrm{wt} \% \mathrm{Fe}-\mathrm{Ni}$ sulfides composed of 50\% pyrite and $50 \%$ pyrrhotite. By contrast, our two polished mounts are depleted in Fe-Ni sulfides by a factor 10 (Table 4). The same depletion was also reported by Franz et al. (2014) who concluded that over 99\% of the sulfur recovered by their chemical extraction from Chassigny $(65 \pm 1 \mathrm{ppm})$ correspond to Ca-sulphates, while a negligible fraction $(<3 \mathrm{ppm})$ correspond to sulfides (pyrite and metal-deficient pyrrhotite, i.e. Chrome Reduced Sulfide, CRS). The bulk-rock Ni budget also reflects the negligible volume of Fe-Ni sulfides in Chassigny. Olivine alone is able to balance the bulk rock Ni contents (500 \pm 70 ppm; Papike et al. 2009) if we combine our analyses of olivine in Table $3(530 \pm 30 \mathrm{ppm} \mathrm{Ni})$ with the olivine modal proportions reported in the literature (91\%; Meyer, 2012). By contrast, the contribution of Fe-Ni sulfides is at best 1-2 ppm (within the analytical error of the bulk-rock Ni content) for the maximum Ni concentration of $3 \mathrm{wt} \%$ in the sulfides and a modal volume of 0.005 \% (Fig. 7).

The amount of sulfide precipitated in Chassigny is negligible compared to the expected huge amount of $\mathrm{S}$ the parental melt was able to dissolve. Because Fe-Ni sulfides preferentially segregated in the intercumulus pores of the meteorite, their amount primarily reflects the low amount of trapped intercumulus silicate melt. Other parameters may also have contributed in 
producing negligible amount of sulfides, i-an unrealistically high degree of partial melting compared to the accepted values, ii-second stage melting of a S-depleted, LREE-depleted olivineaugite mantle source, iii-late-stage migration/removal of intergranular sulfides by percolating fluid(s), iv- S outgassing or sulfide resorption driven by late-stage melt decompression that was coeval with the extrusion of the Chassignite cumulate pile to near-surface conditions. Any further discussion of these parameters will require detailed in-situ geochemical studies of trace metals in Fe-Ni sulfides, which were hitherto made impossible by the very small size of these sulfides (Baumgartner et al., 2017a,b).

\section{In-situ nucleation of Ni-pyrrhotite}

Models based on previously published S contents of Chassigny $(260 \pm 130$ ppm S) suggested that Chassigny Fe-Ni sulfides originated from mixing between cumulates from Sundersaturated melts with S-saturated melts or externally derived evolved melt (see Ding et al. 2015, Baumgartner et al 2017b). The new bulk-rock S estimates (Franz et al. 2014) and our own observations make such interpretations disputable. In-situ nucleation of sulfides from the trapped intercumulus melt is more likely, especially by considering sulfides from olivine-hosted melt inclusions. Such enclosed sulfides resemble early solid micro - precipitate growth in a fluid medium. One may surmise that sulfides appeared very early in these inclusions because the trapped silicate melt fractions were strongly FeO-depleted after massive precipitation of olivine; olivine melt inclusions started crystallizing at high pressure, under conditions of lowered S saturation according to experiments on terrestrial (e.g. Mavrogenes and O'Neill, 1999) and martian basalts (Ding et al., 2015). Pressure above $0.4 \mathrm{Gpa}$ to as high as $2 \mathrm{Gpa}$ were suggested by Nekvasil et al. (2007, 2009), Filiberto (2008) and Giesting (2015). McCubbin et al. (2008) estimated P $=0.9$ Gpa from the crystallization path of Chassigny melt inclusions that contain $0.48-0.67 \mathrm{wt} \% \mathrm{H}_{2} \mathrm{O}$ (He et al. 2013). These high water contents, coupled with high alkali contents, delayed full solidification of olivine-hosted melt inclusions down to $\mathrm{T}=700^{\circ} \mathrm{C}$ (McCubbin et al. 2013). Enclosed pyrrhotites in theory have a solidification temperature of ca. $1200^{\circ} \mathrm{C}$ at 1 bar (Craig and Kullerud, 1969 and 
references therein) that accounts for their segregation as euhedral solid crystals along with apatite and low-Ca pyroxene.

The shape of intergranular assemblages, i.e. ovoid grains or triangular-shaped grains showing convex-inward margins and low dihedral angles with matrix silicates are characteristic of immiscible sulfide blebs forming isolated pockets in cumulate rocks (Naldrett 2005 and references therein). Textural reequilibration that typically affects sulfides in cumulate igneous rocks is recognized through straight triple junctions with olivine and chromite meeting at $120^{\circ}$ indicating surface energy minimization between solids. According to Giesting et al (2015), after accumulation of olivine at $\mathrm{T}=1230^{\circ} \mathrm{C}$ and $0.9-1.7 \mathrm{Gpa}$, the putative lava flow was decompressed from 1 to 0.02 Gpa and cooled rapidly from a point where temperatures were $800-850{ }^{\circ} \mathrm{C}$ at a depth of no more than 200 m (Treiman et al. 2007; McCubbin et al. 2013). The interstitial magma that cooled to form the mesostasis of olivine cumulates experienced retrograde boiling and degassing of volatiles, especially $\mathrm{H}_{2} \mathrm{O}$ (McCubbin and Nekvasil 2008; McCubbin et al. 2013; Giesting et al., 2015). This degassing also triggered complete solidification of the mesostasis at higher $\mathrm{T}\left(>900^{\circ} \mathrm{C}\right)$ compared to melt inclusions in olivine, thus preventing sulfide melts from migrating through the cumulate pile. Chemical equilibrium between sulfides and olivine can be tested with the partitioning behavior of Ni. Despite between-grain variations of $\mathrm{Ni} / \mathrm{Fe}$ on a localized scale, the mean partition coefficient $\mathrm{Kd}$ (Ni/Fesulfides/Ni/Feolivine) calculated from our olivine and pyrrhotite compositions (Fo 68, $0.06 \mathrm{wt} \% \mathrm{NiO}$ for olivine, Table 3 and supplementary data; $2 \pm 0.5 \mathrm{wt} \% \mathrm{Ni}$ for pyrrhotite) is in good agreement with the experimental values determined at magmatic temperatures (19 \pm 5 vs. 13 to 15 ; Brenan, 2003). Thus, an overall state of equilibrium seems to have existed between intergranular (and enclosed) Chassigny pyrrhotite and coexisting olivine as regard the Ni-Fe partitioning. This is expected where sulfides segregated in-situ.

\section{Pyrrhotite compositions track late-magmatic oxidation-crustal contamination}

Our data show that a metal-deficient pyrrhotite composition of general formula $\mathrm{M}_{0.88} \mathrm{~S}(\mathrm{M}$ 
$=\mathrm{Fe}+\mathrm{Ni}+\mathrm{Co}+\mathrm{Cu}+\mathrm{Mn}$ ) is the main igneous sulfide in the Chassigny meteorite. It has long been suggested that disseminated sulfides in volumetrically dominant silicate rocks reequilibrate through redox equilibrium involving coexisting silicate assemblages (Barton 1970). The Chassigny pyrrhotite compositions cluster within a narrow $\operatorname{logfS_{2}}-\mathrm{T}$ domain of Fig. 8, well above the reference buffer curve Fayalite-Magnetite-Quartz-Pyrrhotite (FMQ-Po) at solidus temperature. The accepted magmatic $\mathrm{fO}_{2}$ conditions for Chassigny are slightly below FMQ (FMQ-1.25 log units; McCubbin et al 2013), whether calculated with the equilibrium olivine + low-Ca pyroxene $+\mathrm{Cr}-$ spinel (Treiman et al. 2007) or from V valence-state oxybarometer (Baumgartner et al. 2017b; see also Beck et al. 2006). For such $\mathrm{fO}_{2}$ conditions, the igneous pyrrhotite compositions should be more metal-rich $\left(\mathrm{M}_{0.96} \mathrm{~S}\right)$ at magmatic temperatures compared to the measured composition (Fig.8). Of course, the latter may not be representative of the high temperature pyrrhotite composition because of subsolidus reequilibration. A cooling path following the FMQ-Po reference buffer curve can lower pyrrhotite $\mathrm{M} / \mathrm{S}$ ratios down to at best 0.91 before pyrite starts exsolving at ca $250^{\circ} \mathrm{C}$ (path A; Fig. 8). Nevertheless, the latter value still excludes almost all the measured pyrrhotite compositions. The fugacity of oxygen necessary to reproduce the composition of the Chassigny pyrrhotite can be estimated from the sulfidation reaction of olivine

$2 \mathrm{Fe}_{2} \mathrm{SiO}_{4}+\mathrm{S}_{2}=2 \mathrm{FeS}+\mathrm{Fe}_{2} \mathrm{Si}_{2} \mathrm{O}_{6}+\mathrm{O}_{2}$

Eggler and Lorand (1993) calibrated this equilibrium as a barometer for oxygen and sulfur fugacity. The fugacity of $\mathrm{S}$ is deduced from the FeS isopleths in Fig. 8. Using the compositions of olivine and low-Ca opx in Chassigny ( $\mathrm{Fa}_{32}$ and $\mathrm{En}_{70}$; Meyer, 2012 and Table 3), the sulfidation reaction of olivine indicates an $\mathrm{f}_{\mathrm{O} 2}$ value close to $\mathrm{FMQ}+2 \log$ units at $800-900^{\circ} \mathrm{C}$ (equation 46 in Eggler and Lorand 1993). Such conditions are significantly more oxidizing compared to the $\mathrm{f}_{\mathrm{O} 2}$ range deduced from Cr spinel compositions (McCubbin et al., 2013; Baumgartner et al. 2017b).

The same discrepancy between expected and measured pyrrhotite compositions was documented for nakhlites (Chevrier et al. 2011). Indeed, in addition to their occurrence as extrusive 
flows, nahklites and chassignites share many features as regards their sulfide assemblages, i.e. metal-deficient pyrrhotite predominating over pentlandite and $\mathrm{Cu}$-sulfides. Our pyrrhotite compositions overlap the pyrrhotite compositions so far published for nakhlites (Table 4). Chevrier et al. (2011) suggested that nakhlite pyrrhotites experienced deuteric oxidation resulting from water dissociation and devolatilization of intercumulus melts. Deuteric oxidation results from accumulation of $\mathrm{Fe}^{3+}$-rich minerals raising oxygen fugacity in the latest magmatic differentiates after massive precipitation of $\mathrm{Fe}^{2+}$-rich minerals such as olivine (e.g. Czamanske and Wones 1973). McCubbin and Nekvasil (2008), McCubbin et al. (2013) and Giesting et al. (2015) suggested that degassing changed significantly the $\mathrm{H}_{2} \mathrm{O}$ content of the interstitial magma in the Chassigny cumulate during uplift and eruption or near-surface emplacement. According to these authors, retrograde boiling and degassing may increase oxygen fugacity through the loss of hydrogen while $\mathrm{H}_{2} \mathrm{O}$ losses may account for the lack of biotite and amphibole in the intergranular mesostasis of the Chassigny meteorite. McCubbin and Nekvasil (2008) and McCubbin et al. (2013) interpreted the Cl-enrichment of intercumulus apatites (compared to the olivine-hosted F-rich apatite compositions) as resulting from addition of an exogenous $\mathrm{Cl}$-rich fluid to the intercumulus regions of the Chassigny meteorite above $700{ }^{\circ} \mathrm{C}$. This late-percolating fluid may also have disturbed pyrrhotite compositions if it was introduced into the cumulate horizon sampled by Chassigny immediately after formation and accumulation of the cumulus olivine.

Another potential source of alteration of igneous pyrrhotite composition is assimilation of crustal sulfur coeval driven by magmatic crystallization (Assimilation-Fractional Crystallization process), as suggested by Franz et al (2014) for nakhlites. These authors found Mass Independent Fractionation (MIF) in the $\mathrm{S}$ isotopic composition of sulfides chemically extracted from Nakhla $\left(\Delta^{33} \mathrm{~S}=-0.08 \%\right.$ \% $)$ and Miller Range (MIL) $03346\left(\Delta^{33} \mathrm{~S}=0.434 \pm 0.008 \%\right.$ to $-0.5386 \pm 0.008$ \%). SIMS in-situ analyses confirmed these bulk-rock analyses of MIF, within the error of the chemical extraction analysis for Nakhla, and more variable values for individual pyrrhotite of MIL $03346\left(-0.306 \pm 0.13 \% \circ<\Delta^{33} \mathrm{~S}<-1.116 \pm 0.13 \%\right.$ ). Franz et al (2014) concluded that sulphur salts 
610 (Ca sulfates) or sulphur-bearing fluids were assimilated by parental melts at the time the nakhlite flows were extruded. If valid for nakhlites, this model of exogeneous sulfur assimilation at the magmatic stage is plausible for Chassigny that was part of a subaerial flow erupted on the S-rich Martian surface. However, the very small size of igneous pyrrhotite grains made in-situ SIMS analyses of $\mathrm{S}$ isotope compositions impossible (J. Farqhuar, personal communication to J.-P. Lorand). Only a bulk analysis of the Chrome Reducible Sulfide fraction is available $\left(\Delta^{33} S=0.004\right.$ $\pm 0.008 \%$; Frantz et al, 2014), which, however is a mixture of both igneous metal-deficient pyrrhotite and hydrothermal pyrite. Fig. 10 clearly shows that the assemblage $\mathrm{Ca}$ sulfates $+\mathrm{a}$ metal-deficient pyrrhotite $\left(\mathrm{Fe}_{0.88} \mathrm{~S}\right)$ produce the same oxidizing conditions (FMQ $+1.5 \log$ unit) as those defined by the sulfidation reaction of olivine. One may speculate that, because of its exceedingly low modal volume, Chassigny pyrrhotite reequilibrated under the redox conditions imposed by assimilation of sulfates, without reequilibrating for $\mathrm{S}$ isotopic compositions. Of course, such a reequilibration is assumed to have started before isolation of olivine-hosted melt inclusions inside olivine.

\section{CONCLUSION}

PGEs), the parental melt of the Chassigny dunitic cumulate achieved sulfide-saturation at a late stage of its crystallization, after olivine and chromite precipitation. Igneous sulfides precipitated insitu as magmatic sulfide melt of low-Ni pyrrhotite bulk composition, either inside porphyritic silicate melt inclusions in olivine or as polyhedral or near-spherical blebs in intergranular spaces between cumulus olivine. The igneous pyrrhotite displays $\mathrm{Ni} / \mathrm{Fe}$ ratios within the range expected for equilibration with the coexisting olivine at igneous temperatures.

Chassigny sulfides bear imprints of each petrogenetic process experienced by the Chassigny meteorite. Once segregated, the pyrrhotite experienced a late-magmatic reequilibration of its metal- 
to-sulfur ratios toward a general formula $\mathrm{M}_{0.88 \pm 0.01} \mathrm{~S}(\mathrm{M}=\mathrm{Fe}+\mathrm{Ni}+\mathrm{Co}+\mathrm{Cu}+\mathrm{Mn})$. This reequilibration may result from retrograde boiling, volatile loss, or contamination by crustal sulfates, perhaps driven by post-cumulus circulation of late-magmatic differentiated melts.

Hydrothermal fluids operated pervasively over different temperatures well after complete cooling of the Chassigny dunite. Magmatic pyrrhotite was converted to pyrite along with other accessory sulfides (e.g. millerite), in line with low-temperature precipitation of $\mathrm{Ca}$ sulfate $+\mathrm{Ca}$ carbonate deposition. The shock that ejected the Chassigny meteorite from Mars generated postshock temperatures high enough $\left(300^{\circ} \mathrm{C}\right)$ to anneal and rehomogenize Ni inside pyrrhotite while pyrite blebs were fractured and disrupted into subgrains by shock metamorphism. Owing to its high density of fractures, pyrite was preferentially oxidized on Earth compared to pyrrhotite.

Hydrothermal alteration and shock metamorphism generated strong heterogeneity inside the Chassigny meteorite. This is demonstrated by the distribution of pyrite, marcasite, and an FeS phase (troilite) between each piece of the meteorite investigated so far for Fe-Ni sulfides.

Acknowledgement Financial funding was provided by a INSU 2014-PNP grant (JPL). The authors thank Michel Fialin (Camparis) for his help with electron microprobe analyses.

Barton, P.B. (1970) Sulfide petrology. Mineral Society of America Special Paper, 3, 187-198.

Baumgartner, R., Fiorentini, M.L., Lorand, J.-P., Baratoux, D., Zaccarini, F., Ferrière, L., Prasek, M., and Sener, K. (2017a) The role of sulfides in the fractionation of highly siderophile and chalcophile elements during the formation of Martian shergottite meteorites. Geochimica Cosmochimica Acta, 210, 1-24.

Baumgartner, R.J., Fiorentini, M.L., Baratoux, D., Ferrière, L., Locmelis, M., Tomkins, A. and 
Sener, A. K. (2017b) The variability of ruthenium in chromite from Chassignite and olivinephyric shergottite meteorites: new insights into the behavior of PGE and sulfur in Martian magmatic systems. Meteroritics and Planetary Science, 52, 333-350

Belzile, N., Chen, Y. W., Cai, C. F. and Li, Y. (2004) A review on pyrrhotite oxidation. Journal of Geochemical Exploration, 84, 65-76.

Beck, P., Gillet, P., Barrat, J.-A., Wadhwa, M., Greenwood, R. C., Franchi, I .A., Bohn, M., Cotten, J., Van de Moortele, B. and Reynard, B. (2006) Petrography and geochemistry of the Chassignite Northwest Africa 2737 (NWA 2737). Geochimica Cosmochimica Acta, 70, $2127-2139$.

Bogard, D. D., and Garrison, D. H. (2008) ${ }^{39} \mathrm{Ar}-40 \mathrm{Ar}$ age and thermal history of Martian dunite NWA 2737. Earth and Planetary Science Letters, 273, 386-392.

Boctor, N.Z., Wang, J., Alexander, C.M.O., Hauri, E. (2006) Volatile abundances and hydrogen isotope signatures of melt inclusions and nominally anhydrous minerals in the Chassignites and ALH84001 (abs\#1412). Lunar Planet. Sci. XXXVII Lunar Planetary Institute, Houston

Brandon, A.D., Walker, R.J., Morgan, J., and Goles, G.G. (2000) Re-Os isotopic evidence for early differentiation of the Martian mantle. Geochimica Cosmochimica Acta, 64, 4083-4095.

Brandon, A.D., Puchtel I. S., Walker, R. J., Day, J.M.D., Irving, A.J. and Taylor L.A. (2012) Evolution of the Martian mantle inferred from the 187Re-187Os isotope and highly siderophile element abundance systematics of shergottite meteorites. Geochimica Cosmochimica Acta, 76, 206-235. 
Brenan, J.M. (2003) Effects of $\mathrm{f}_{\mathrm{O} 2}, \mathrm{f}_{\mathrm{S} 2}$, temperature, and melt composition on Fe-Ni exchange between olivine and sulfide liquid: Implications for natural olivine-sulfide assemblages. Geochimica Cosmochimica Acta, 67, 2663-2681.

Brenan, J.M., Bennett, N.R. and Zajacz, Z. (2016) Experimental results on fractionation of the highly siderophile elements (HSE) at variable pressures and temperatures during planetary and magmatic differentiation. Review in Mineralogy and Geochemistry, 81, 1-88.

Bridges, J.C., Catling, D.C., Saxton, J.M., Swindle, T.D., Lyon, I., and Grady, M.M. (2001) Alteration assemblages in Martian meteorites: Implications for near-surface processes. Space Science Review, 96, 365-392.

Chandra, A.P. and Gerson, A.R. (2011) Pyrite (FeS2) oxidation: A sub-micron synchrotron investigation of the initial steps. Geochimica Cosmochimica Acta, 75, 6239-6254.

Chevrier, V., Lorand, J.-P. and Sautter, V. (2011) Sulfide petrology of four Nakhlites (NWA817, NWA998, Nakhla, Governador Valadares). Meteroritics and Planetary Science, 46, 769-784.

Cox, S.F. (1987) Flow mechanisms in sulphide minerals. Ore Geology Review, 2, 133-7.

Craig, J.R. (1973) Pentlandite-pyrrhotite and other low-temperature relations in the Fe-Ni-S system. American Journal of Science, 273, 496-510.

Craig, J. R. and Kullerud, G. (1969) Phase relations in the Cu-Fe-Ni-S system and their applications to magmatic ore deposits. Economic Geology Monography 4, 344-358. 
Craig, J. R. and Vokes, F. M. (1993) The metamorphism of pyrite and pyritic ores: an overview. Mineralogical Magazine, 57, 3-18.

Czamanske, G.K. and Wones, D.R. (1973) Oxidation during magmatic differentiation, Finnmarka complex, Oslo area, Norway: Part 2. The mafic silicates. Journal of Petrology, 14, 349-380.

Day, J.M.D., Taylor, L. A., Floss, C. and McSween, H. Y. Jr. (2006) Petrology and chemistry of MIL 03346 and its significance in understanding the petrogenesis of Nakhlites on Mars. Meteroritics and Planetary Science, 41, 581-606.

Dehouck, E., Chevrier, V., Gaudin, A., Mangold, N., Mathé, P.E. and Rochette, P. (2012) Evaluating the role of sulfide-weathering in the formation of sulfates or carbonates on Mars. Geochimica et Cosmochimica Acta, 90, 47-63.

Delaney, J.S. and Dyar, M.D. (2001) Magmatic magnetite in Martian meteorite melt inclusions from Chassigny (abs). Meteroritics and Planetary Science, 36, A48.

Ding, S., Dasgupta, R., Lee, C. T. A and Wadhwa, M. (2015) New bulk sulfur measurements of Martian meteorites and modeling the fate of sulfur during melting and crystallizationImplications for sulfur transfer from Martian mantle to crust-atmosphere system. Earth and Planetary Science Letters, 409, 157-167.

Eggler, D.H. and Lorand, J.-P. (1993) Mantle sulfide oxybarometry. Geochimica et Cosmochimica Acta, 57, 2213-2222. 
Etschmann, B., Pring, A., Putnis, A., Grguric, B. A. and Studer, A. (2004) A kinetic study of the exsolution of pentlandite $(\mathrm{Ni}, \mathrm{Fe}) 9 \mathrm{~S} 8$ from the monosulfide solid solution $(\mathrm{Fe}, \mathrm{Ni}) \mathrm{S}$. American Mineralogist, 89, 39-50.

Foley, C.N., Economou, T. and Clayton, R. N. (2003) Final chemical results from the Mars Pathfinder Alpha Proton X-ray Spectrometer. Journal of Geophysical Research 108, 8096, doi:10.1029/2002JE002019.

Farquhar, J., Savarino, J., Jackson, T.L., Thiemens, M.H. (2000) Evidence of atmospheric sulphur in the Martian regolith from sulphur isotopes in meteorites. Nature, 404, 50-52.

Farquhar, J., Kim, S.-T. and Masterson, A. (2007) Implications from sulphur isotopes of the Nakhla meteorite origin of sulfate on Mars. Earth and Planetary Science Letters, 264, 1-8.

Filiberto, J. (2008) Experimental constraints on the parental liquid of the Chassigny meteorite: A possible link between the Chassigny meteorite and a Martian Gusev basalt. Geochimica et Cosmochimica Acta, 72, 690-701.

Fleet, M.E. (1978) The pyrrhotite-marcasite transformation. Canadian Mineralogist, 16, 31-35.

Floran, R.J., Prinz, M., Hlava, P.F., Keil, K., Nehru, C.E. and Hinthorne, J.R. (1978) The Chassigny meteorite. Geochimica et Cosmochimica Acta, 42, 1213-1229.

Franz, H.B., Kim, S.T., Farquhar, J., Day, J.M.D., Economos, R., McKeegan K.D., Schmitt, A.K., Irving, A.J., Hoek, J. and Dottin, J. (2014) Isotopic links between atmospheric chemistry and the deep sulphur cycle on Mars. Nature, 508, 364-368. 
Gattacceca, J., Hewins, R.J., Lorand, J.-P., Rochette, P., Lagroix, F., Cournède, C., Uehara, M., Pont, S., Sautter, V., Scorzelli, R.B., Hombourger, C., Munayco, P., Zanda, B. and Chennaoui, H. (2013) Opaque minerals, magnetic properties and paleomagnetism of the Tissint Martian meteorite. Meteroritics and Planetary Science,48,1919-1936.

Giesting, P.A., Schwenzer, S.P., Filiberto, J., Starkey, N.A., Franchi, I.A., Treiman, A.H., Tindle, A. and Grady, M.M. (2015) Igneous and shock processes affecting chassignite amphibole evaluated using chlorine/water partitioning and hydrogen isotopes. Meteoritics and Planetary Science, 50, 433-460.

Gibson, E.K., Moore, C.B., Primus, T.M. and Lewis, C.F. (1985) Sulfur in achondritic meteorites. Meteroritics and Planetary Science, 20, 503-511.

Greenwood, J.P., Mojzsis, S.J. and Coath, C.D. (2000a) Sulfur isotopic compositions of individual sulfides in Martian meteorites ALH84001 and Nakhla: implications for crust-regolith exchange on Mars. Earth and Planetary Science Letters, 184, 23-30.

Greenwood, J.P., Riciputi, L.R., McSween, H.Y. and Taylor, L.A. (2000b) Modified sulfur isotopic compositons of sulfides in the Nakhlites and Chassigny. Geochimica et Cosmochimica Acta, 64,1121-1131.

Hall, A.J. (1986) Pyrite-pyrrhotine redox reactions in nature. Mineralogical Magazine, 50, 223-

Harries, D., Pollok, K. and Langenhorst, F. (2013) Oxidative dissolution of 4C- and Nc pyrrhotite: intrinsic reactivity differences, $\mathrm{pH}$ dependence, and the effect of anisotropy. Geochimica et Cosmochimica Acta, 102, 23-44. 
Harvey, R.P., McSween HYJr (1992) Petrogenesis of the nakhlite meteorites: Evidence from cumulate mineral zoning. Geochimica et Cosmochimica Acta 56, 1655-1663.

797

Hayes, S.M., Root R.A., Perdrial, N., Maier, R.M. and Chorover, J. (2014) Surficial weathering of iron sulfide mine tailings under semi-arid climate. Geochimica et Cosmochimica Acta, 141, $240-257$.

He, Q., Xiao, L., Hsu, W., Balta, J.B., McSween, H.Y. and Liu, Y. ( 2013) The water content and parental magma of the second Chassignite NWA 2737: Clues from trapped melt inclusions in olivine. Meteroritics and Planetary Science, 48, 474-492.

Herd, C.D.K., Borg, L., Jones, J.H. and Papike, J. J. (2002) Oxygen fugacity and geochemical variations in the Martian basalts: Implications for Martian basalt petrogenesis and the oxidation state of the upper mantle of Mars. Geochimica et Cosmochimica Acta, 66, 2025-2036.

Hewins, R.H., Zanda, B., Pont, S., Humayun, M., Assayag, N. and Cartigny, P. ( 2015) Northwest Africa 8694, a ferroan Chassignite (abstract \# 2249). 46th Lunar and Planetary Science Conference. CD-ROM.

Holwell, D.A., Adeyemia, Z., Warda, L.A., Smith, D.J., Graham, S.D., McDonald, I. and Smith, J.W. (2017) Low temperature alteration of magmatic Ni-Cu-PGE sulfides as a source for hydrothermal Ni and PGE ores: A quantitative approach using automated mineralogy. Ore Geology Review, 91, 718-740.

Huminicki, D.M.C. and Rimstidt, J.D. (2009) Iron oxyhydroxide coating of pyrite for acid mine drainage control. Applied Geochemistry, 24, 1626-1634. 
Imae, N. and Ikeda, Y. (2007) Petrology of the Miller Range 03346 nakhlite in comparison with the Yamato-000593 nakhlite. Meteroritics and Planetary Science, 42,171-184.

Janzen, M.P., Nicholson, R.V. and Scharer, J.M. (2000) Pyrrhotite reaction kinetics: reaction rates for oxidation by oxygen, ferric iron, and for nonoxidative dissolution. Geochimica et Cosmochimica Acta, 64, 1511-1522.

Jerz, J.K. and Rimstidt, J.D. (2004) Pyrite oxidation in moist air. Geochimica et Cosmochimica Acta, 68, 701-714.

Johnson, M.C., Rutherford, M.J. and Hess, P.C. (1991) Chassigny petrogenesis: Melt compositions, intensive parameters, and water contents of Martian magmas. Geochimica et Cosmochimica Acta, 55, 349-366.

Kanipayacharoen, W. and Boudreau, A.E. (2013) Sulfide-associated mineral assemblages in the Bushveld complex, South Africa: platinum-group element enrichment by vapor refining by chloride-carbonate fluids. Mineralogical Deposita, 48, 193-210.

Kerber, L., Forget, F. and Wordsworth, R. (2015) Sulfur in the early Martian atmosphere revisited: Experiments with a 3-D Global Climate Model. Icarus, 261, 133-148.

King, P.L. and McLennan, S.M. (2010) Sulfur on Mars. Elements, 6,107-112.

Kissin, S.A. and Scott, S.D. (1982). Phase relations involving pyrrhotite below $350^{\circ} \mathrm{C}$. Economic Geology, 77, 1739-1755.

Langenhorst, F. and Greshake, A. (1999) A transmission electron microscope study of Chassigny: 
Evidence for strong shock metamorphism. Meteroritics and Planetary Science, 34, 43-48.

Leshin, L.A., Epstein, S. and Stolper, E. M. (1996) Hydrogen isotope geochemistry of SNC meteorites. Geochimica Cosmochimica Acta, 60, 2635-2650.

Liu, R., Wolfe, A.L., Dzombak, D.A., Horwitz, C.P., Stewart, B.W. and Capo, R.C. (2009) Controlled electrochemical dissolution of hydrothermal and sedimentary pyrite. Applied Geochemistry, 24, 836-842.

Lorand, J.-P., Alard, O. (2011) Pyrite tracks assimilation of crustal sulfur in some Pyrenean lherzolites. Mineralogy Petrology, 101, 115-128.

Lorand, J.-P., Barat, J.-A., Chevrier, V., Sautter, V. and Pont, S. (2012) Metal-saturated sulfide assemblages in Chassignite NWA 2737; evidence for impact-related sulfur devolatilisation. Meteroritics and Planetary Science, 47, 1830-1841.

Lorand, J.-P., Chevrier, V. and Sautter, V. (2005) Sulfide mineralogy and redox conditions in some Shergottites. Meteroritics and Planetary Science, 40, 1257-1272.

Lorand, J.-P., Hewins, R. H., Pont, S., Zanda, B., Humayun, M., Nemchin, A . and others (2015) Nickeliferous pyrite tracks late hydrothermalism in Martian regolith breccia NWA 7533. Meteroritics and Planetary Science, 50, 2099-2120.

Malavergne, V., Guyot, F., Benzerara, K. and Martinez, I. (2002) Descriptions of new shockinduced phases in the Shergotty, Zagami, Nakhla and Chassigny meteorites. Meteroritics and Planetary Science, 36, 1297-1305. 
Mavrogènes, J.A., O’Neill, H.S.C. (1999) The relative effects of pressure, temperature and oxygen fugacity on the solubility of sulfide in mafic magmas. Geochimica et Cosmochimica Acta, 63, 1173- 1180 .

McClay, K.R. and Ellis, P.G. (1983) Deformation and recrystallization of pyrite. Mineralogical Magazine 47, 527-538.

McCubbin, F. M. and Nekvasil, H. (2008) Maskelynite-hosted apatite in the Chassigny meteorite: Insights into late-stage magmatic volatile evolution in Martian magmas. American Mineralogist, 93, 676-684.

McCubbin, F.M., Nekvasil, H., Harrington, A.D., Elardo, S.M. and Lindsley, D. H. (2008) Compositional diversity and stratification of the Martian crust: Inferences from crystallization experiments on the picrobasalt Humphrey from Gusev crater, Mars. Journal of Geophysical Research-Planets 113:E11013. doi:10.1029/2008JE003165

McCubbin, F.M., Elardo, S.M. and Shearer, C.K. Jr (2013) A petrogenetic model for the comagmatic origin of Chassignites and Nakhlites: Inferences from chlorine-rich minerals, petrology and geochemistry. Meteroritics and Planetary Science, 48, 819-853.

McSween, H.Y. Jr (2001) The rocks of Mars, from far and near. Meteroritics and Planetary Science, $37,7-25$.

McSween, H.Y. Jr and McLennan, S.M. (2014). Mars. Treatise on Geochemistry, 2nd edition, Chapter 2.10, . Editor: Executive Editors: Heinrich D. Holland and Karl K. Turekian, pp 251282.

McSween, H.Y. Jr and Treiman A.H. (1998) Planetary Materials. Martian Meteorites. Reviews in 
Meyer, C. (2012) The Martian Meteorite Compendium. Astromaterials Research \& Exploration Science (ARES). http://curator.jsc.nasa.gov/antmet/mmc/.

Mycroft J. R., Nesbitt H. W. and Pratt A. R. (1995) X-ray photoelectron and Auger electron spectroscopy of air-oxidized pyrrhotite: Distribution of oxidized species with depth. Geochimica et Cosmochimica Acta, 59, 721-733.

Murowchick, J.B. (1992) Marcasite inversion and the petrographic determination of pyrite ancestry. Economic Geology, 87,1141-1152.

Naldrett, A.J., Craig, J.R. and Kullerud, G. (1967) The central portion of the Fe-Ni-S system and 
its bearing on pentlandite exsolution in iron-nickel sulfide ores. Economic Geology, 62, 826847.

Nekvasil, H., Filiberto, J., McCubbin, F. and Lindsley D.H. (2007) Alkalic parental magmas for Chassignites? Meteroritics and Planetary Science, 42, 979-992.

Nekvasil, H., McCubbin, F.M., Harrington, A., Elardo, S. and Lindsley D.H. (2009) Linking the Chassigny meteorite and the Martian surface rock Backstay: Insights into igneous crustal differentiation processes on Mars. Meteroritics and Planetary Science, 44, 853-869.

Nesbitt, H.W., Bancroft, G.M., Pratt, A.R. and Scaini, M.J. (1998) Sulfur and iron surface states on fractured pyrite surfaces. American Mineralogist, 83, 1067-1076.

Nyquist, L.E, Bogard, D. D., Shih, C.Y., Greshake, A., Stöffler, D. and Eugster, O. (2001) Ages and geological histories of Martian meteorites. Space Science Reviews, 96,105-164.

Papike, J.J., Karner, J.M., Shearer, C.M. and Burger, P.V. (2009) Silicate mineralogy of Martian meteorites. Geochimica Cosmochimica Acta, 73,7443-7485.

Parat, F, Holz, F. and Streck, M.J. (2011) Sulfur-bearing Magmatic Accessory Minerals. Review in Mineralogy and Geochemistry, 73, pp. 285-333.

Pistollet (1816) The circumstances of the Chassigny meteorite shower. Annales Chimie et Physique (Paris) v. 1, pp 45-48.

Pratt, A.R., Muir, I.J. and Nesbitt, H.W. (1994) X-ray photoelectron and Auger electron spectroscopic studies of pyrrhotite and mechanism of air oxidation. Geochimica et 
Raghavan, V. (2004). Fe-Ni-S (Iron-Nickel-Sulfur) system. Journal of Phase Equilibrium Diffraction, 25, 373-381.

Reid, A.M. and Bunch, T. E. (1975) The Nakhlites part II: Where, when and how. Meteoritics, 10, 317.

Rickard, D. and Luther, G.W. (2007) Chemistry of Iron Sulfides, 107, 514-562.

Rimstidt, J.D. and Vaughan, D.J. (2003) Pyrite oxidation: a state-of-the-art assessment of the reaction mechanism. Geochimica et Cosmochimica Acta, 67, 873-880.

Shearer, C.K., Layne, G.D., Papike, J.J. and Spilde, M.N. (1996) Sulfur isotopic systematics in alteration assemblages in Martian meteorite Allan Hills 84001. Geochimica et Cosmochimica Acta, 60, 2921-2926.

Skinner, W.M., Nesbitt, H.W. and Pratt, A.R. (2004) XPS identification of bulk hole defects and iterant Fe 3d electrons in natural trolite (FeS). Geochimica et Cosmochimica Acta, 68, 22592263.

Tian, F., Mark, W., Claire, B., Jacob, D., Haqq, M., Megan Smith, Crisp, D.C., Catling, D., Zahnle, K. and Kasting, J.F. (2010) Photochemical and climate consequences of sulfur outgassing on early Mars. Earth and Planetary Science Letters, 295, 412-418.

Thornber, M.R. (1975) Supergene alteration of sulphides. I. Chemical model based on massive nickel sulphide deposits at Kambalda, Western Australia. Chemical Geology, 15, 1—14. 
Thomas, J.E., Jones, C.F., Skinner, W.M. and Smart, R.St. C. (1998) The role of surface sulfur species in the inhibition of pyrrhotite dissolution in acid conditions. Geochimica et Cosmochimica Acta, 62, 1555- 1565.

Thomas, J.E., Skinner, W.M., Smart, R.St. C. (2001) A mechanism to explain sudden changes in rates and products for pyrrhotite dissolution in acid solution. Geochimica et Cosmochimica Acta, 65, 1-12.

Todd, E.C., Sherman, D.M. and Purton, J.A. (2003) Surface oxidation of pyrite under ambient atmospheric and aqueous $(\mathrm{pH}=2$ to 10$)$ conditions: electronic structure and mineralogy from X-ray absorption spectroscopy. Geochimica et Cosmochimica Acta, 67, 881-893.

Toulmin, P. and Barton, P.B. (1964) A thermodynamic study of pyrite and pyrrhotite. Geochimica et Cosmochimica Acta, 68, 641-671.

Treiman, A.H., Gleason, J.D., and Bogard, D.D. (2000) The SNC meteorites are from Mars. Planetary Space Sciences, 48, 1213-1230.

Treiman, A.H., Dyar, M. D., McCanta, M., Noble, S.K. and Pieters, C.M. (2007) Martian dunite NWA 2737: Petrographic constraints on geological history, shock events, and olivine color. Journal of Geophysical Research- Planets 112:E04002. doi:10.1029/2006JE002777.

Treiman, A.H. and Irving, A.J. (2008) Petrology of Martian meteorite Northwest Africa 998. Meteroritics and Planetary Science,43, 829-854.

Varela, M.E., Kurat, G., Bonnin-Mosbah, M., Clocchiatti, R. and Massare, D. (2000) Glassbearing inclusions in olivine of the Chassigny achondrite: Heterogeneous trapping at sub- 
1006 Wadhwa, M. and Crozaz, G. (1995a) Trace and minor elements in minerals of Nakhlites and 1007 Chassigny: Clues to their petrogenesis. Geochimica et Cosmochimica Acta, 59, 3629-3647.

Watmuff, I.G. (1974) Supergene alteration of the Mt Windara nickel sulfides ores deposits, Western Australia. Mineralium Deposita, 9, 199-211.

Wentworth, S.J. and Gooding, J.L. (1994) Carbonates and sulfates in the Chassigny meteorite: Further evidence for aqueous chemistry on the SNC parent planet. Meteroritics and Planetary Science, 29,860-863.

\section{Figure captions}

FIGURE 1: Low-magnification backscattered electron (BSE) image of the Chassigny meteorite 
investigated in this study.

FIGURE 2: Microphotographs of Chassigny sulfides. 2a: pyrrhotite included in an olivine-hosted melt inclusion (reflected light optical microscope). 2b: intergranular pyrrhotite hosted in a feldspar pocket enclosing euhedral chromite (reflected light optical microscope); 2c: detail of Fig. 2b showing a two-phase (pyrrhotite + pentlandite) ellipsoidal magmatic sulfide grain associated with a euhedral apatite inclusion inside the feldspar glass (BSE image). 2d: intergranular pyrrhotite (+ pentlandite) at triple junction of olivine crystals (reflected light optical microscope). 2e: polyhedral intergranular pyrrhotite (+ pentlandite) showing convex-inward grain boundaries (BSE image). 2f: highly fractured, rounded pyrite grain showing incipient replacement by an NiS phase (BSE image). 2g: intergranular pyrite showing formation of subgrains (BSE image). 2h: rounded and highly granulated pyrite (white) showing incipient alteration in Fe oxyhydroxides (reflected light optical microscope; oil immersion objective). Ol: olivine; Opx: orthopyroxene; Chr: chromite; Ap: apatite; Amph: amphibole; Fs: feldspar; Po: pyrrhotite; Py: pyrite; Pn: pentlandite; Fe oxhyd: Fe oxyhydroxide.

FIGURE 3: Distribution of sulfide grain sizes in the Chassigny meteorite.

FIGURE 4: Metal-to-sulfur atomic ratios $(\mathrm{M} / \mathrm{S} ; \mathrm{M}=\mathrm{Fe}+\mathrm{Ni}+\mathrm{Co}+\mathrm{Cu}+\mathrm{Mn})$ of Chassigny pyrrhotite (WDS analyses only). $\mathrm{Fe}_{7} \mathrm{~S}_{8}$ : monoclinic pyrrhotite; $\mathrm{Fe}_{9} \mathrm{~S}_{10}$ : hexagonal pyrrhotite (Kissin and Scott, 1982)

FIGURE 5: Ni concentrations (wt\%) in pyrrhotite and pyrite (WDS analyses only). $\mathrm{N}=$ number of analyses. 
analyses only).

1057

FIGURE 7: Plot of Chassigny pyrrhotite compositions (squares) in the Fe-Ni-S system at $300^{\circ} \mathrm{C}$. Compositional range and phase relationships of Mss (monosulfide solid solution) from Naldrett et al (1967), Craig (1973) and Rhagavan, (2004). $\mathrm{Fe}_{7} \mathrm{~S}_{8}$ : monoclinic pyrrhotite; $\mathrm{Fe}_{9} \mathrm{~S}_{10}$ : hexagonal pyrrhotite; FeS: troïlite (Kissin and Scott, 1982).

FIGURE 8: Plot of the mean composition of Chassigny pyrrhotite $\left(\mathrm{M}_{0.88} \mathrm{~S}\right.$; white star) in the $\log$ $\mathrm{fS}_{2}$ - T diagram for the Fe-S-O system (after Lorand et al., 2005 and Chevrier et al., 2011). Pyrrhotite isopleths of metal-to-sulfur atomic ratios, pyrrhotite iron (Fe-Po) and sulfur vapor-sulfur liquid (Svap-Sliq) reaction curves from Toulmin and Barton (1964). The curves labeled with oxygen fugacity are for the reaction: $3 \mathrm{FeS}+2 \mathrm{O}_{2}=\mathrm{Fe}_{3} \mathrm{O}_{4}+\mathrm{S}_{2}$ (pyrrhotite-magnetite equilibrium); FMQ-Po buffer from Eggler and Lorand (1993). We present two possible subsolidus evolutions for the Chassigny igneous pyrrhotite. Path A assumes subsolidus re-equilibration controlled by the FMQ-Po buffer curve (see text for description of the buffer). Note that path A precludes pyrrhotite $\mathrm{M} / \mathrm{S}$ ratios $<0.91$. Path $\mathrm{B}$ assumes cooling of the Chassigny pyrrhotite at constant $\mathrm{M} / \mathrm{S}$ ratio. Path A should trigger pyrite exsolution at high temperature, and then increasing $\mathrm{M} / \mathrm{S}$ ratios in the coexisting pyrrhotite down to 0.91 .

FIGURE 9: Low-temperature $\left(135^{\circ} \mathrm{C}\right)$ phase relationships in the Fe-Ni-S system (wt \%) after Craig (1973) and Rhagavan (2004)(wt\%). This diagram illustrates a putative reaction path (arrow) at decreasing $\mathrm{Fe} / \mathrm{Ni}$ ratio producing pyrite $+\mathrm{NiS}$ from the igneous sulfide assemblage of Chassigny (pyrrhotite + pentlandite). Mss1 and Mss 2: compositional field of monosulfide solid solutions 1 and 2 from Craig (1973). Py: pyrite; Mpo: monoclinic pyrrhotite $\left(\mathrm{Fe}_{7} \mathrm{~S}_{8}\right)$; Hpo: hexagonal pyrrhotite $\left(\mathrm{Fe}_{9} \mathrm{~S}_{10}\right)$; Tr: troïlite $(\mathrm{FeS})$; Pn: pentlandite, Mi: millerite; Vs: vaesite; Vi: violarite; Gd: godlevskite; Hz: heazlewoodite. 
FIGURE 10: $\log \mathrm{fS}_{2}$ vs. $\log \mathrm{fO}_{2}$ diagram for the Fe-S-O system at $800^{\circ} \mathrm{C}$ (after Parat et al., 2011).

1084 The compositional range of Chassigny pyrrhotite can coexist with anhydrite if the oxygen fugacity 1085 is above that defined by the synthetic assemblage FMQ (Fayalite-Magnetite-Quartz); $\mathrm{Fe}_{7} \mathrm{~S}_{8}$ : 1086 monoclinic pyrrhotite; $\mathrm{Fe}_{9} \mathrm{~S}_{10}$ : hexagonal pyrrhotite (Kissin and Scott, 1982).

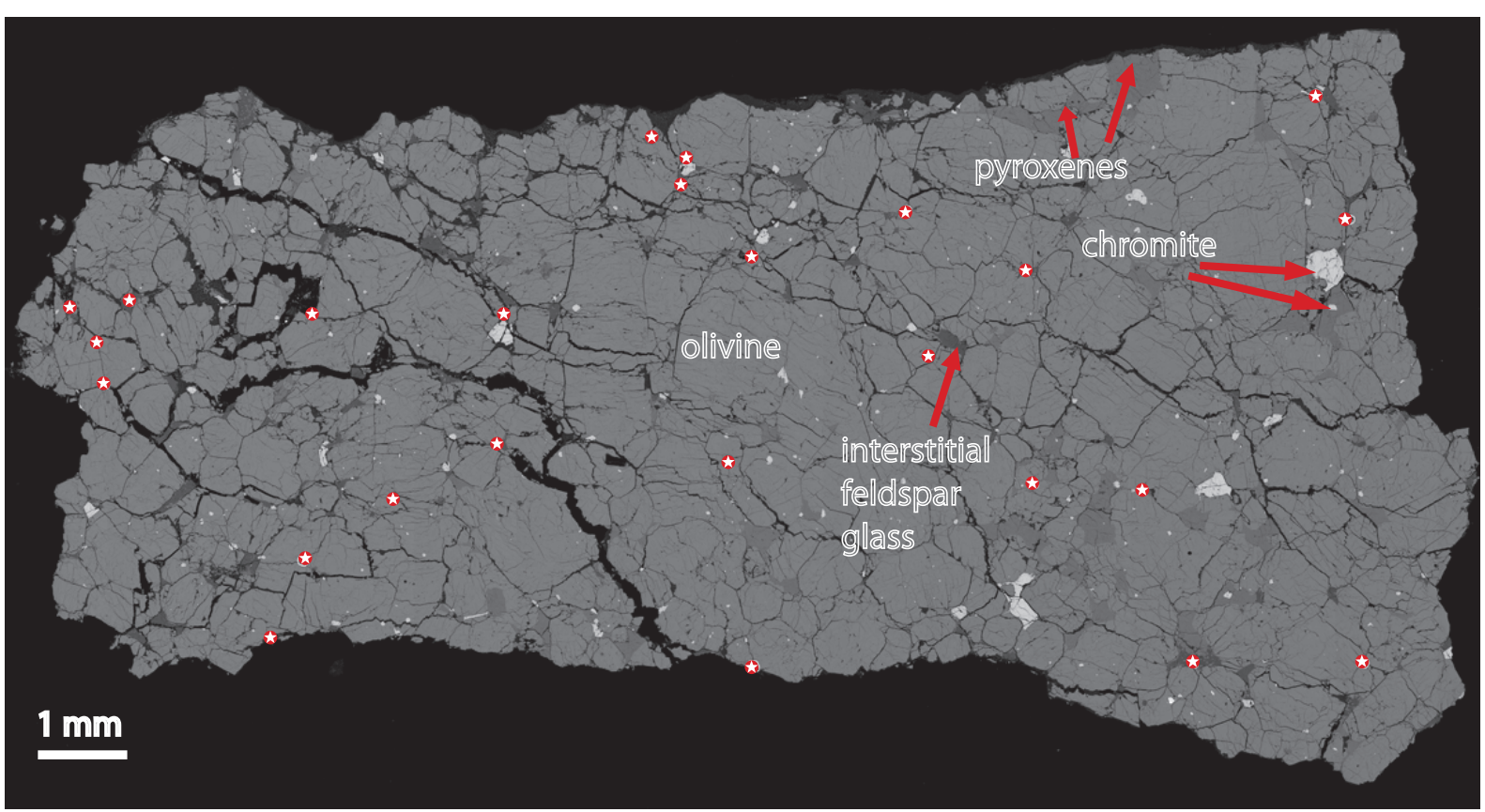



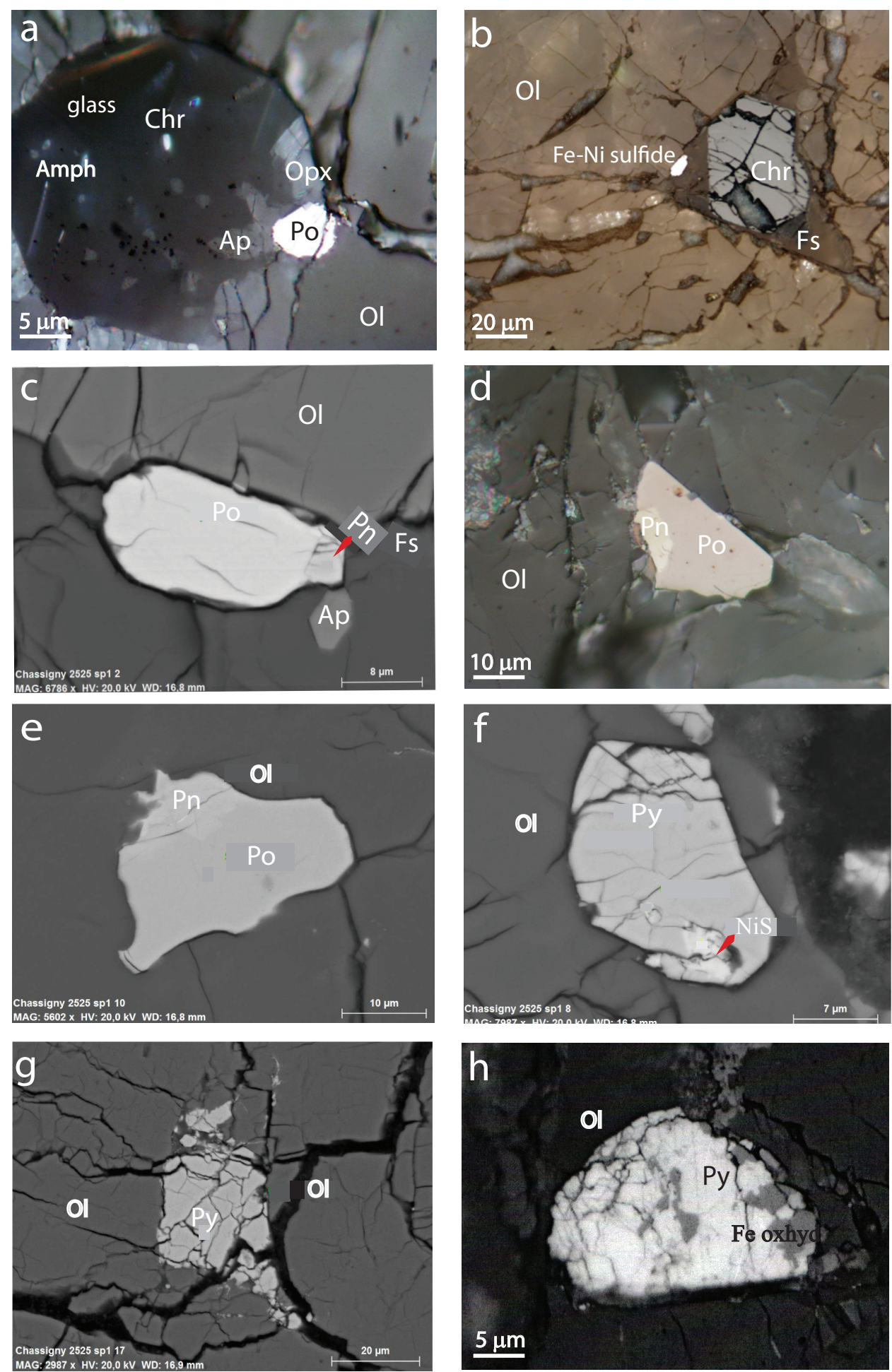

Fig. 2 
Number of sulfide grains

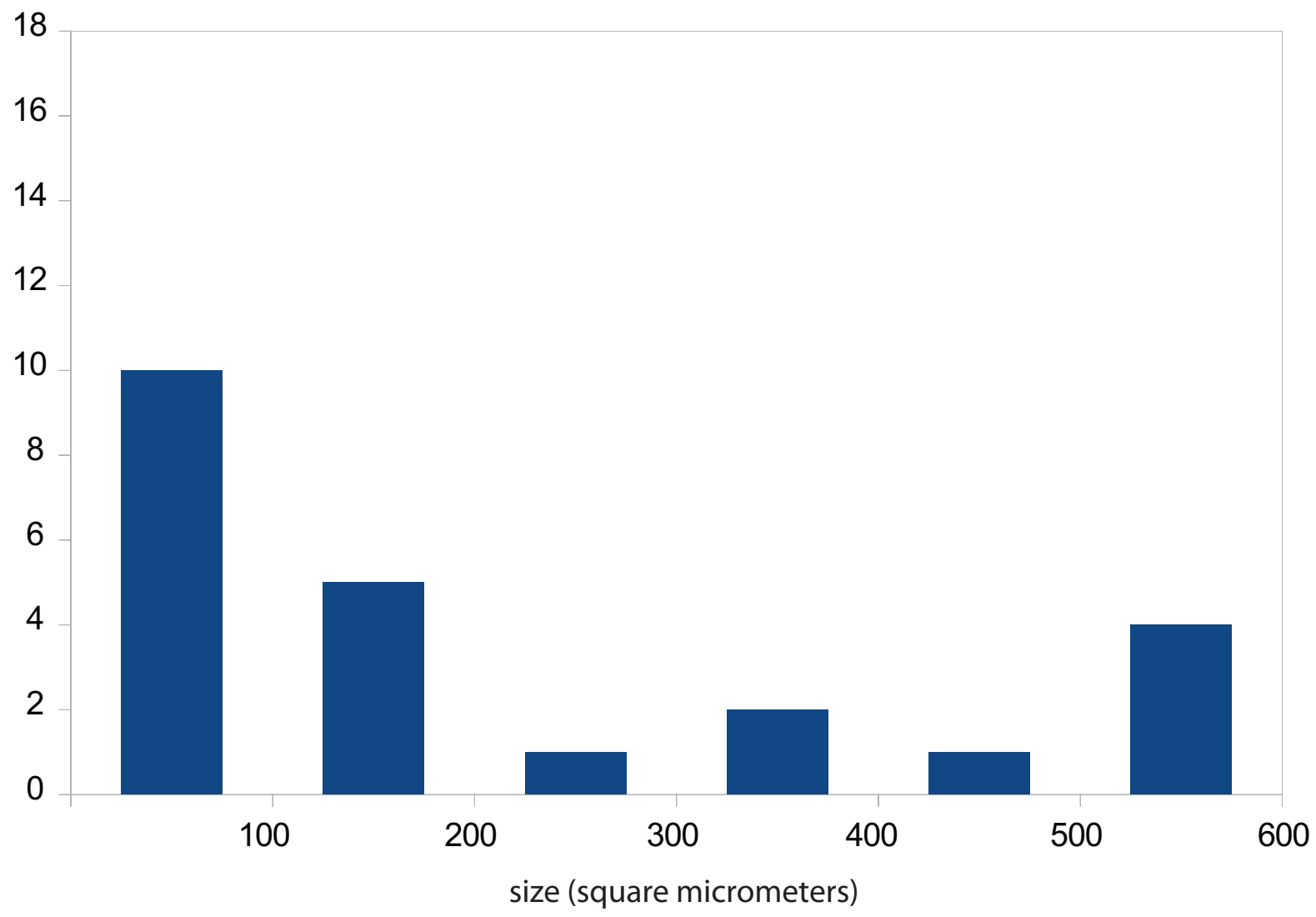

Fig. 3 


\section{number of analyses}

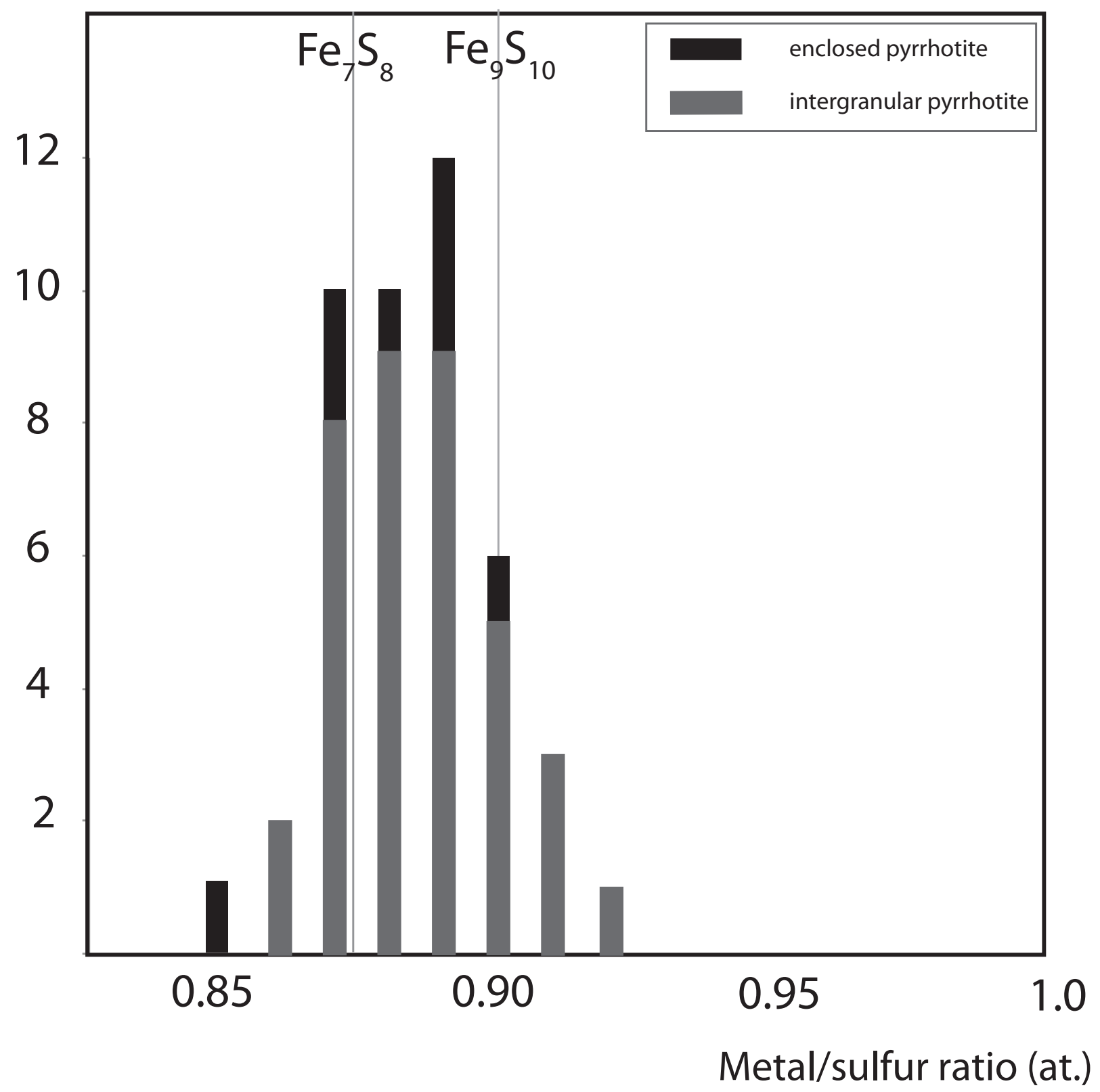

Fig. 4 


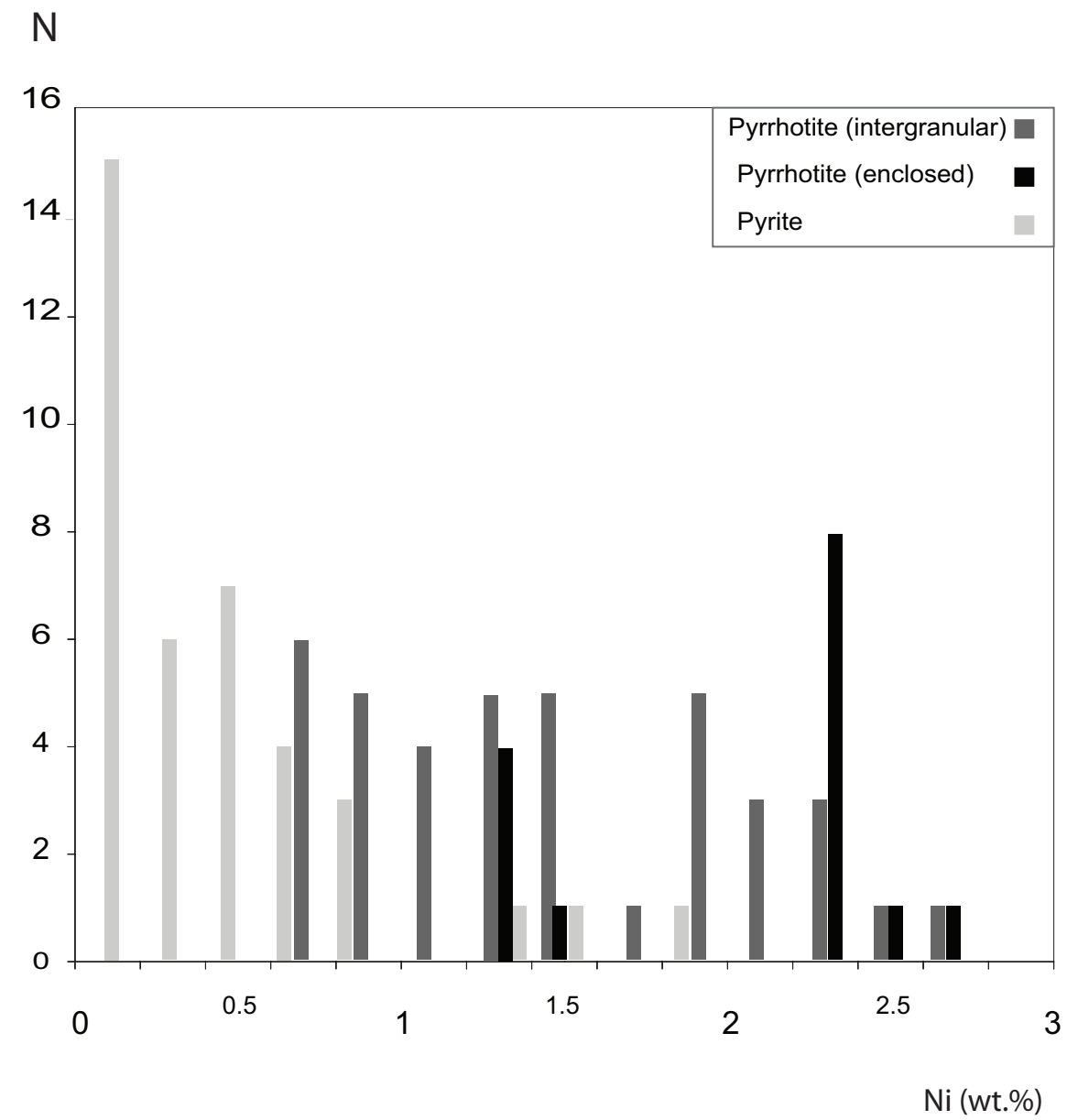

1091

Fig. 5 
metal/sulfur(at.)

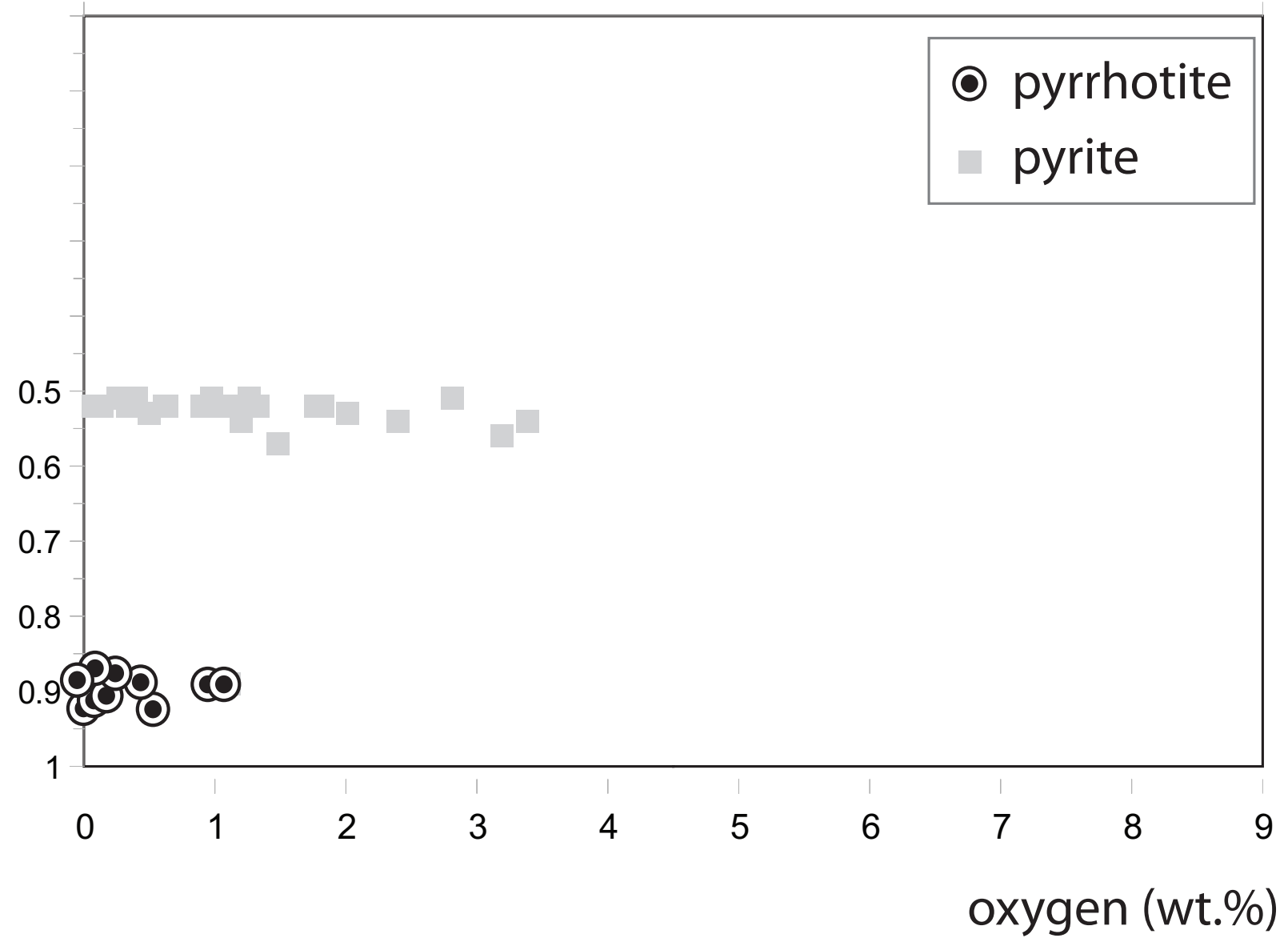

Fig. 6 


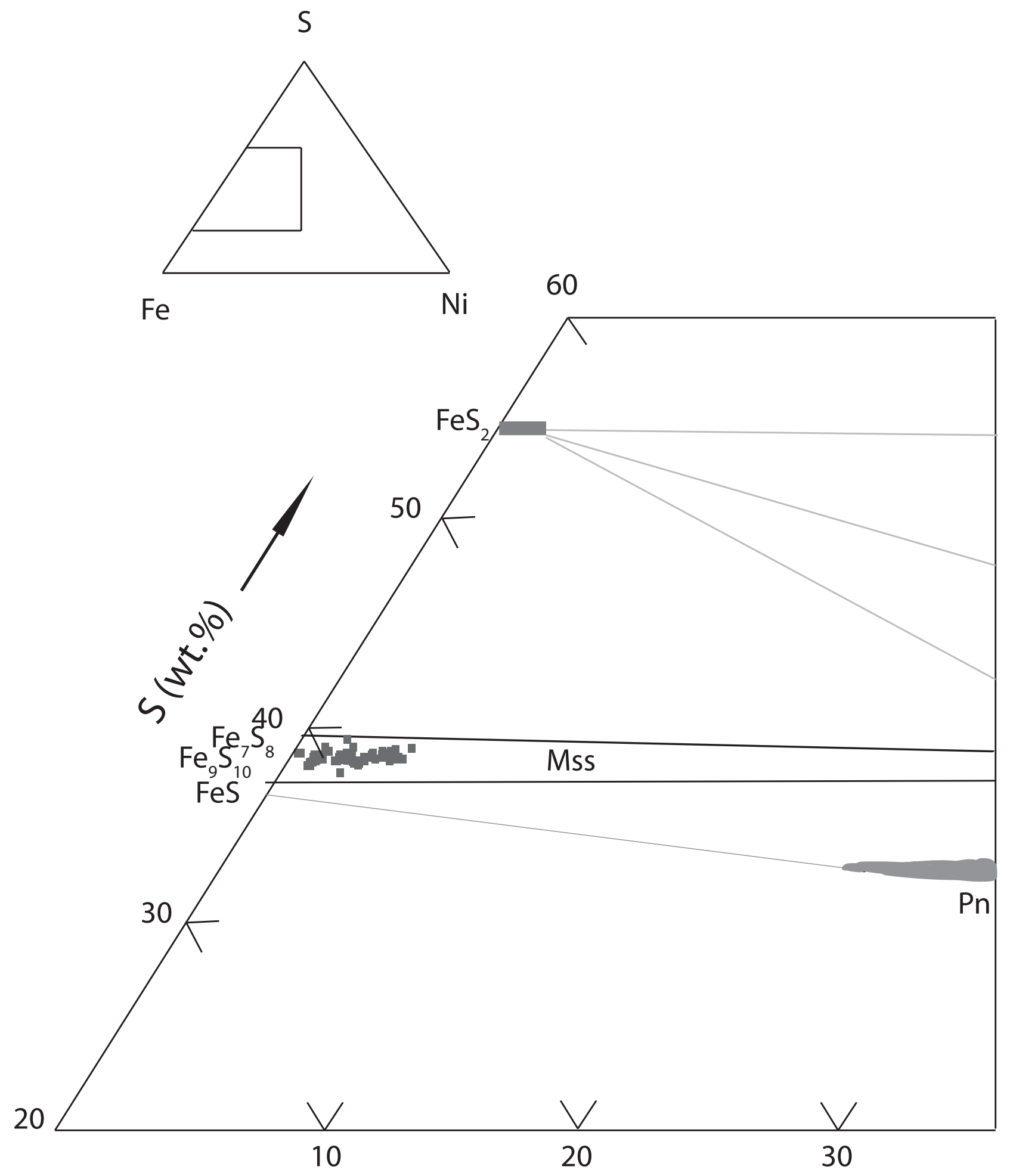

Ni (wt.\%)

Fig. 7 


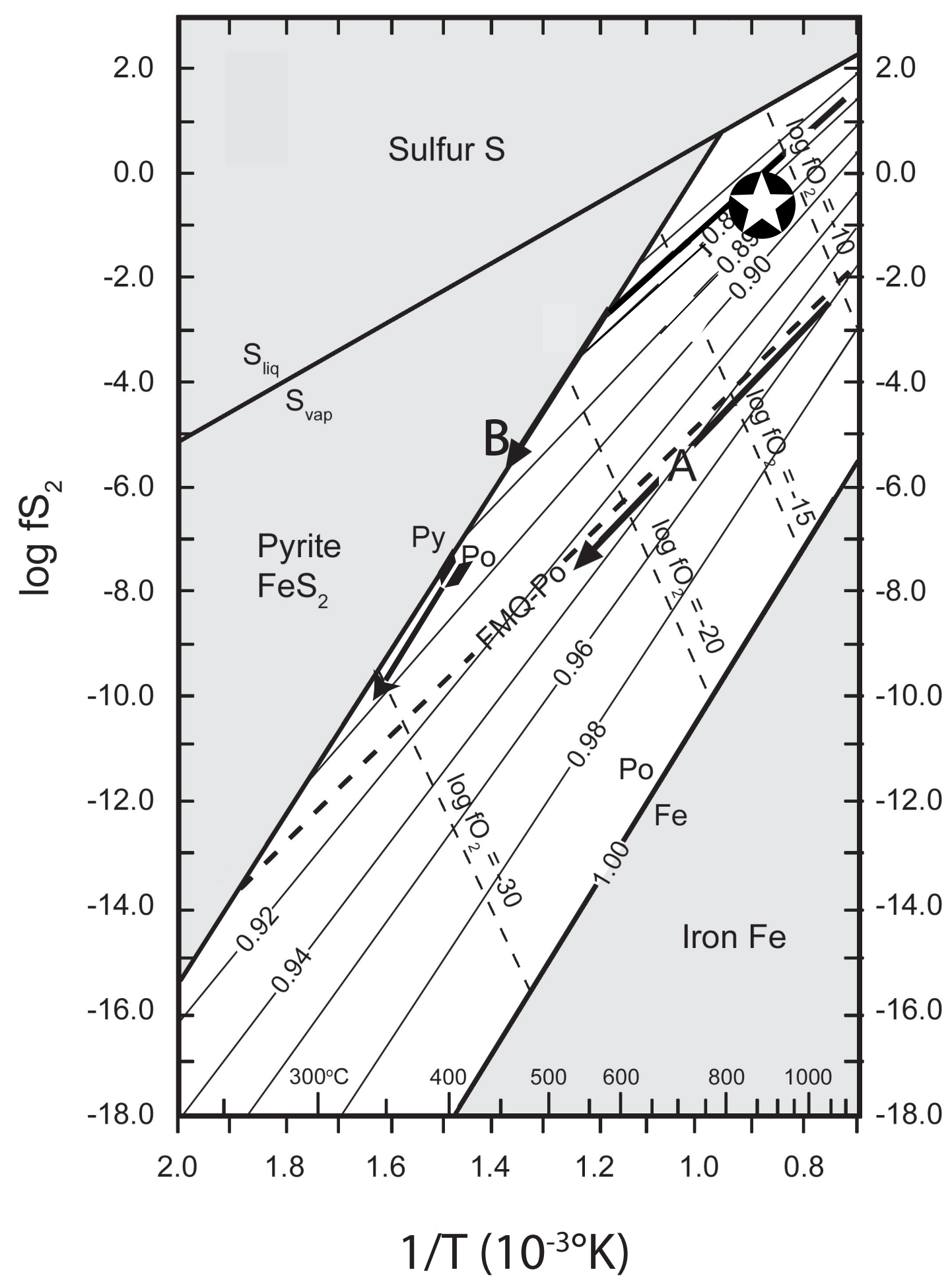

Fig. 8 


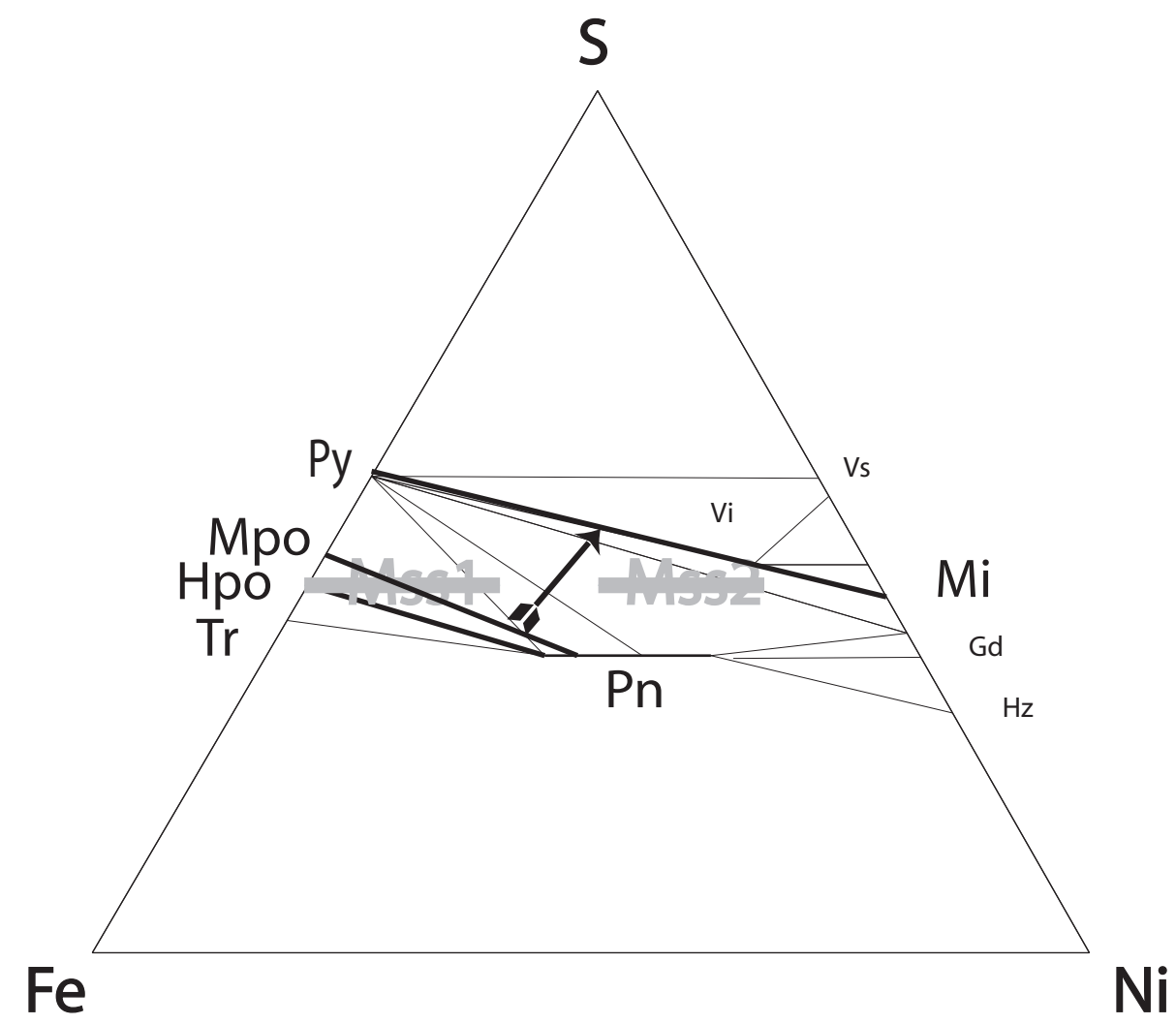

Fig. 9 


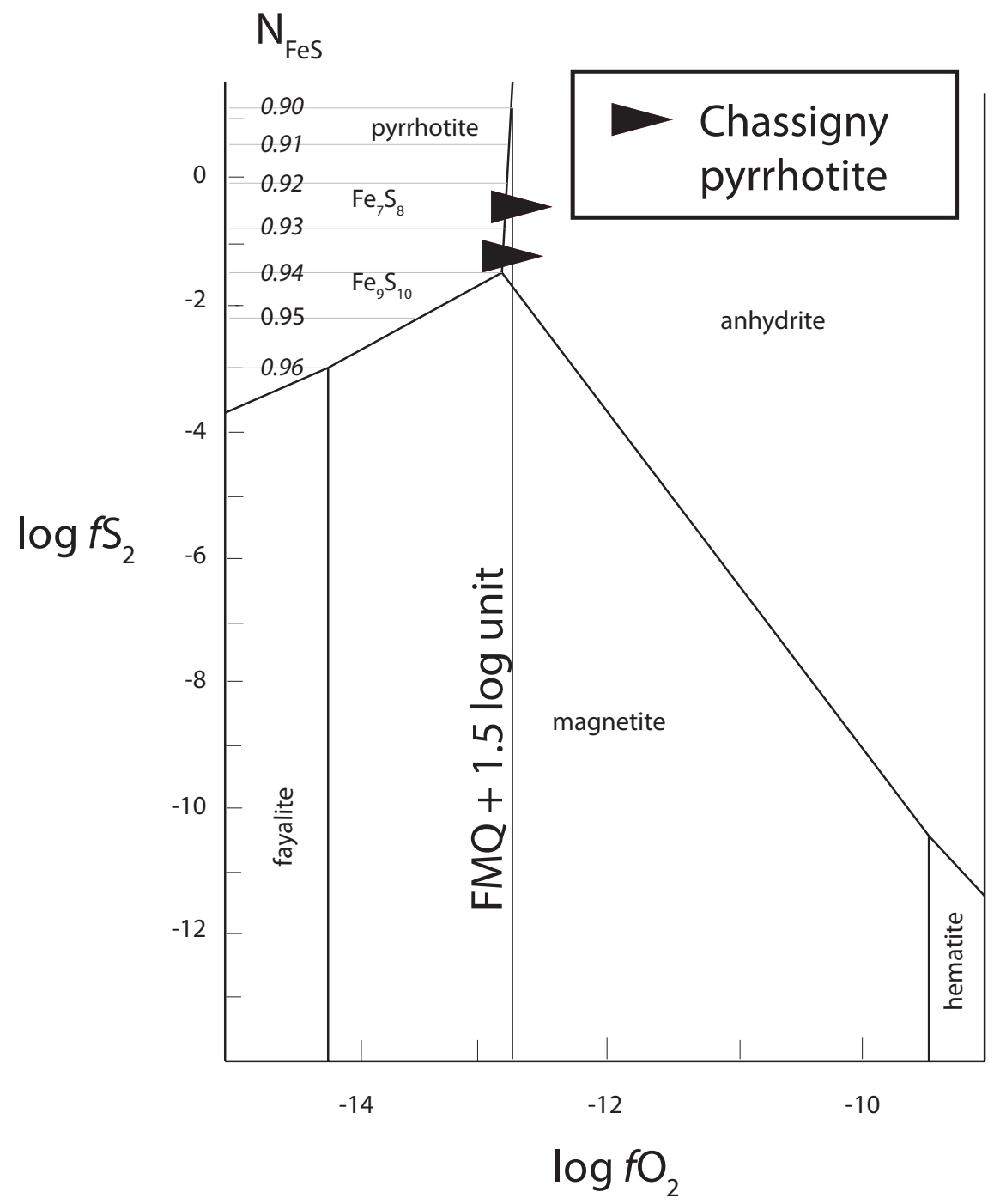


1104

1105

1106

1107

1108

1109

1110

1111

1112

1113

1114

1115

1116

1117

1118

1119

1120
(A) $n=5$
(B) $n=36$
(C) $\mathrm{n}=10$

\begin{tabular}{lc}
\hline $\mathrm{wt} \%$ & \\
$\mathrm{Fe}$ & $63.45 \pm 0.05$ \\
$\mathrm{Ni}$ & - \\
$\mathrm{Co}$ & - \\
$\mathrm{S}$ & $36.53 \pm 0.03$ \\
total & 99.98 \\
& \\
$\mathrm{M} / \mathrm{S}$ & 0.999 \\
& $\mathrm{SEM}$
\end{tabular}

A : Gattaceca et al. (2013), B : Chevrier et al. (2011), C : Lorand et al. (2012). = : number of analyses. M/S : metal/sulfur atomic ratio $(\mathrm{M}=\mathrm{Fe}+\mathrm{Ni}+\mathrm{Co})$. - : below detection limit $(<0.05 \mathrm{wt} \%)$. SEM : scanning electron microscope standardless procedure (Muséum National d'Histoire Naturelle, Paris); EMP : electron microprobe analysis (Camparis).

Table 2: Representative analyses of Fe-Ni sulfides from the Chassigny meteorite

\begin{tabular}{|c|c|c|c|c|c|c|c|}
\hline mineral & E Po & E Po & E Po & I Po & I Po & I Po & I Po \\
\hline $\begin{array}{l}\text { sulfide grain } \\
\mathrm{wt} \%\end{array}$ & Po5113 & Pod10 & Pod 10 & Pod11 & Pod11 & Pod11 & Po3h2 \\
\hline $\mathrm{Fe}$ & 59.08 & 56.15 & 58.0 & 57.73 & 57.27 & 58.24 & 58.51 \\
\hline $\mathrm{Ni}$ & 1.5 & 2.77 & 2.54 & 2.52 & 2.62 & 2.50 & 2.37 \\
\hline $\mathrm{Co}$ & - & 0.09 & - & - & - & - & 0.26 \\
\hline $\mathrm{Cu}$ & - & - & 0.15 & - & - & 0.17 & - \\
\hline $\mathrm{Mn}$ & - & 0.1 & - & - & - & 0.05 & - \\
\hline $\mathrm{Zn}$ & - & - & - & 0.08 & - & - & - \\
\hline $\mathrm{S}$ & 38.8 & 39.78 & 39.1 & 39.57 & 39.67 & 39.17 & 39.60 \\
\hline $\mathrm{O}$ & - & - & - & na & na & 0.20 & 0.18 \\
\hline Total & 99.38 & 98.89 & 97.79 & 99.90 & 99.56 & 100.34 & 100.92 \\
\hline $\mathrm{M} / \mathrm{S}$ & 0.89 & 0.87 & 0.88 & 0.88 & 0.88 & 0.89 & 0.88 \\
\hline mineral & I Po & I Po & I Po & I Po & I Po & I Po & *I Pn \\
\hline $\begin{array}{l}\text { sulfide grain } \\
\mathrm{wt} \%\end{array}$ & Po3h2 & Po3h2 & Pola16 & Po1a16 & Pola16 & Po7C10 & Po1a16 \\
\hline $\mathrm{Fe}$ & 58.02 & 58.14 & 58.8 & 60.45 & 59.57 & 60.65 & 32.88 \\
\hline $\mathrm{Ni}$ & 2.35 & 2.14 & 1.75 & 1.4 & 2.0 & 1.03 & 32.94 \\
\hline $\mathrm{Co}$ & 0.05 & 0.17 & 0.2 & - & - & - & - \\
\hline $\mathrm{Cu}$ & - & - & - & - & 0.15 & - & - \\
\hline $\mathrm{Mn}$ & - & - & - & - & - & - & - \\
\hline $\mathrm{Zn}$ & - & 0.08 & - & - & - & - & - \\
\hline S & 39.62 & 39.22 & 38.6 & 39.36 & 39.16 & 38.80 & 34.18 \\
\hline $\mathrm{O}$ & 0.08 & na & na & 0.05 & 0.07 & 0.07 & na \\
\hline Total & 100.12 & 99.75 & 99.41 & 101.26 & 100.95 & 100.55 & 100.0 \\
\hline $\mathrm{M} / \mathrm{S}$ & 0.88 & 0.875 & 0.90 & 0.88 & 0.89 & 0.91 & 1.08 \\
\hline $\begin{array}{l}\text { mineral } \\
\text { sulfide grain } \\
w t \%\end{array}$ & $\begin{array}{l}\text { I Py } \\
\text { Pyb7 }\end{array}$ & $\begin{array}{l}\text { I Py } \\
\text { Py6e17 }\end{array}$ & I Py & I Py & I Py & I Py & *I Mi \\
\hline
\end{tabular}




\begin{tabular}{llllllll}
$\mathrm{Fe}$ & 46.57 & 45.54 & 47.28 & 46.23 & 45.35 & 44.24 & 3.89 \\
$\mathrm{Ni}$ & 0.1 & 0.94 & 0.46 & 0.46 & 1.49 & 0.53 & 61.89 \\
$\mathrm{Co}$ & - & - & - & - & - & 0.11 & - \\
$\mathrm{Cu}$ & 0.05 & & - & - & 0.06 & 0.05 & - \\
$\mathrm{Mn}$ & - & - & - & - & - & - \\
$\mathrm{Zn}$ & - & - & - & 0.18 & 0.49 & 0.90 & - \\
$\mathrm{S}$ & 53.23 & 53.91 & 52.37 & 51.7 & 48.65 & 48.07 & 34.5 \\
$\mathrm{O}$ & $\mathrm{na}$ & $\mathrm{na}$ & 0.63 & 1.19 & 3.19 & 4.26 & na \\
Total & 99.94 & 100.39 & 100.74 & 99.66 & 99.13 & 98.16 & 99.28 \\
& & & & & & & \\
$\mathrm{M} / \mathrm{S}$ & 0.5 & 0.51 & 0.54 & 0.52 & 0.56 & 0.53 & 1.04 \\
\hline
\end{tabular}

E Po : enclosed pyrrhotite; I Po : intergranular pyrrhotite; I Pn : intergranular pentlandite I Py : intergranular pyrite; I Mi ; intergranular millerite ; EMP analyses except *

(EDS analyses); na : not analysed ; - : below detection limits $(<0.05 \mathrm{wt} \%)$.

Table 3: Electron microprobe analyses of Chassigny olivine

Mean (27 analyses)

$\mathrm{Wt} \%$

$\mathrm{SiO}_{2}$

$\mathrm{TiO}_{2}$

$\mathrm{Al}_{2} \mathrm{O}_{3}$

$\mathrm{Cr}_{2} \mathrm{O}_{3}$

$\mathrm{FeO}$

$\mathrm{MgO}$

$\mathrm{MnO}$

$\mathrm{NiO}$

$\mathrm{CaO}$

Total
37.40

28.1

34.13

0.50

0.06

0.13

100.32
Standard deviation

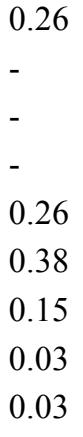

0.26

0.38

0.15

(0.03

(1)

$\mathrm{Mg} / \mathrm{Mg}+\mathrm{Fe}^{2+}$ (at.)

- : below detection limit $(<0.05$ wt \%) 
ratio

1138

1139 Nakhlites

$1140 \quad$ NWA 817

$0.02 \pm 0.01^{1}$

$0.874 \pm 0.01^{1}$

1141 MIL nakhlites

$0.042^{2}$

$0.89^{2}-0.90^{3}$

$1142 \quad$ Yamato nakhlites

$0.86-0.88^{4}$

$1143 \quad$ Nakhla

$0.04 \pm 0.013^{1}$

$0.88 \pm 0.02^{1}$

Governador Valadares

$0.88^{5}$

1146

Lafayette

$0.037 \pm 0.012^{1}$

$0.88 \pm 0.016^{1}$

$1148 \quad$ NWA 998

$0.08 \pm 0.03^{1}$

$0.87^{5}$

1149

$0.04^{6}$

1150 Chassignites

1151 Chassigny

$0.005^{7}$

$0.88 \pm 0.01^{7}$

$1152 \quad$ NWA 2737

$0.01 \pm 0.005^{8}$

$1.05^{8}$

1153

1154

1 : Chevrier et al (2011); 2 : Day et al. (2006), 3 : Frantz et al., (2014); $4:$ Imae and Ikeda (2007); $5:$ Greenwood et al.

1155 (2000a); 6 : Irving and Treiman (2008); 7 : This study; 8 : Lorand et al. (2012).

1156

1157 